
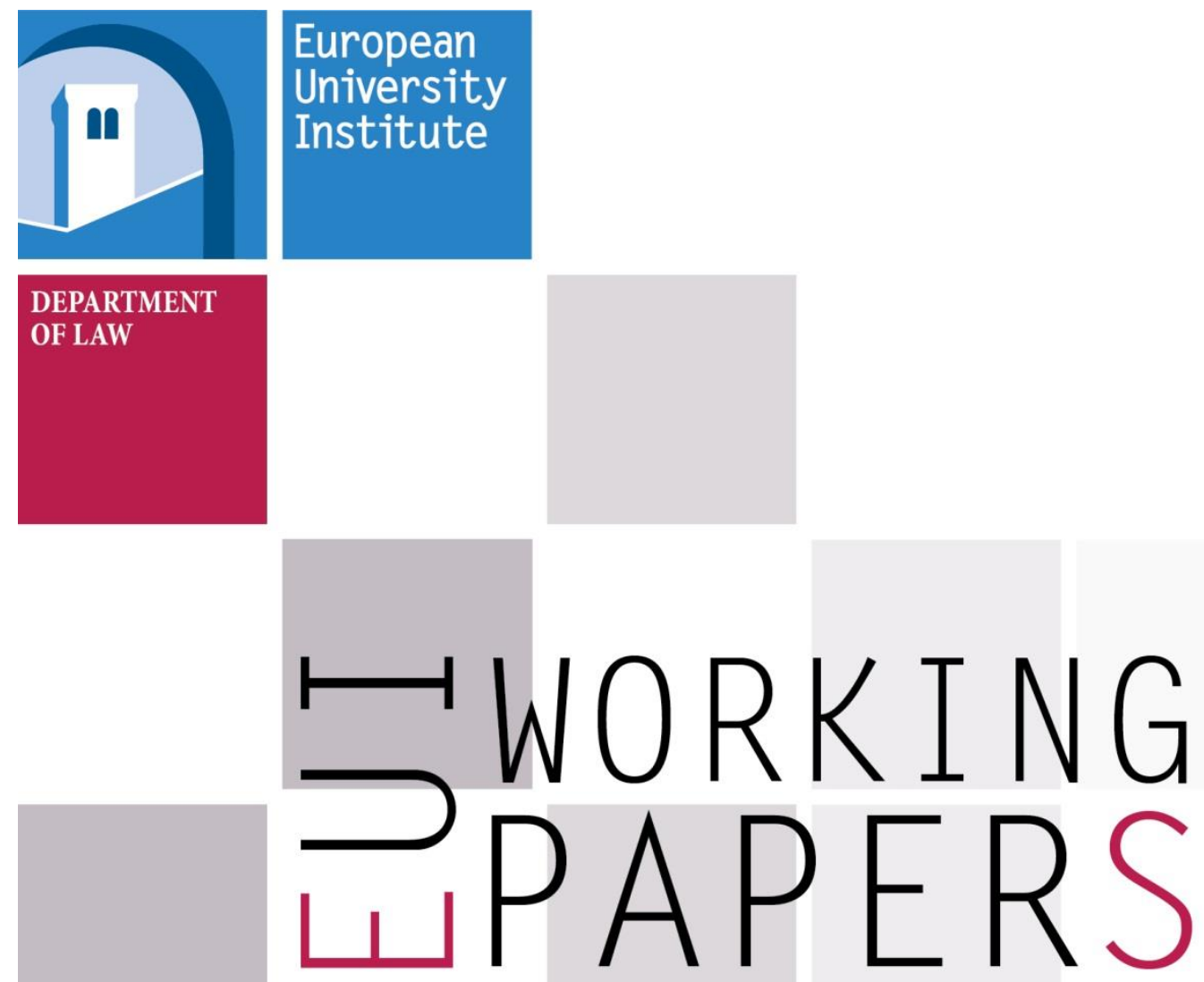

LAW 2015/03

Department of Law

European Regulatory Private Law Project (ERC-ERPL-10) European Research Council (ERC) Grant

\title{
Bottom up or Rock Bottom Harmonization? Francovich State Liability in National Courts
}

Rónán Condon and Barend van Leeuwen (eds.)

In cooperation with Mihalis Dekastros, Leticia Díez Sánchez, Federico della Negra, Przemyslaw Pałka, Maria Jose Schmidt-Kessen, Mira Turpeinen and Hubert de Verdelhan

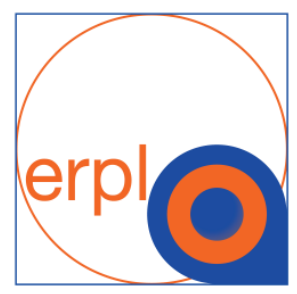



European University Institute

\section{Department of Law}

"European Regulatory Private Law" Project

European Research Council (ERC) Grant

Bottom up or Rock Bottom Harmonization?

Francovich State Liability in National Courts

Rónán Condon and Barend van Leeuwen (eds.)

In cooperation with Mihalis Dekastros, Leticia Díez Sánchez, Federico della Negra, Przemyslaw Pałka, Maria Jose Schmidt-Kessen, Mira Turpeinen

and Hubert de Verdelhan

EUI Working Paper LAW 2015/03

ERC-ERPL-10

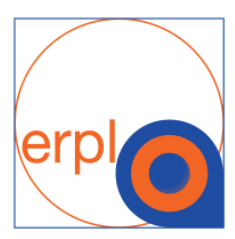


This text may be downloaded for personal research purposes only. Any additional reproduction for other purposes, whether in hard copy or electronically, requires the consent of the author(s), editor(s). If cited or quoted, reference should be made to the full name of the author(s), editor(s), the title, the working paper or other series, the year, and the publisher.

ISSN 1725-6739

C 2015 Rónán Condon and Barend van Leeuwen

Printed in Italy

European University Institute

Badia Fiesolana

I - 50014 San Domenico di Fiesole (FI)

Italy

www.eui.eu 


\section{European Regulatory Private Law: The Transformation of European Private Law from Autonomy to Functionalism in Competition and Regulation (ERPL)}

A 60 month European Research Council grant has been awarded to Prof. Hans-Wolfgang Micklitz for the project "European Regulatory Private Law: the Transformation of European Private Law from Autonomy to Functionalism in Competition and Regulation" (ERPL). The focus of the socio-legal project lies in the search for a normative model which could shape a self-sufficient European private legal order in its interaction with national private law systems. The project aims at a new-orientation of the structures and methods of European private law based on its transformation from autonomy to functionalism in competition and regulation. It suggests the emergence of a self-sufficient European private law, composed of three different layers (1) the sectorial substance of ERPL, (2) the general principles - provisionally termed competitive contract law - and (3) common principles of civil law. It elaborates on the interaction between ERPL and national private law systems around four normative models: (1) intrusion and substitution, (2) conflict and resistance, (3) hybridisation and (4) convergence. It analyses the new order of values, enshrined in the concept of access justice (Zugangsgerechtigkeit).

The research leading to these results has received funding from the European Research Council under the European Union's Seventh Framework Programme (FP/2007-2013) / ERC Grant Agreement n. [269722].

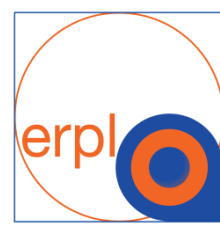


Editors' Contact Details

\section{Rónán Condon}

Phd Researcher In Law

European University Institute

Florence, Italy

E-Mail: Ronan.Condon@Eui.Eu

Barend van Leeuwen

Phd Researcher In Law

European University Institute

Florence, Italy

E-Mail: Barend.vanLeeuwen@Eui.Eu 


\begin{abstract}
The Working Paper presents the first results of a research project on the application of Francovich State liability by national courts. The project is supervised by Prof. Hans-W. Micklitz (EUI) and Prof. Takis Tridimas (KCL). Research has been undertaken in ten Member States to identify all cases in which State liability on the basis of the Francovich criteria was claimed in national courts. For each case researchers were asked to complete a case sheet. Finally, they were asked to write a short report with the results for their Member State. The conclusion analyses some of the trends. It is clear that, while national courts have not opposed the application of the conditions for Francovich State liability, they are still struggling to integrate these conditions in their national laws on State liability. The result can only be described as something of a hybrid, which requires further analysis in the future. It is hoped that this Working Paper will provide a sound basis for further research.
\end{abstract}

\title{
Keywords
}

Francovich, State liability, hybridisation, relationship national courts - CJEU 



\section{Table of Contents}

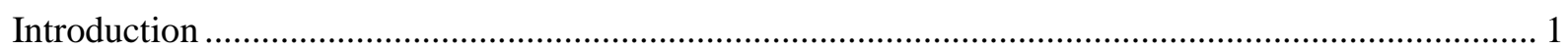

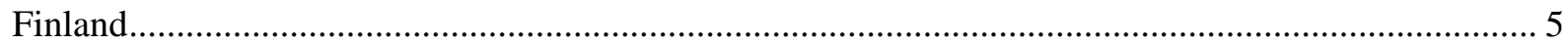

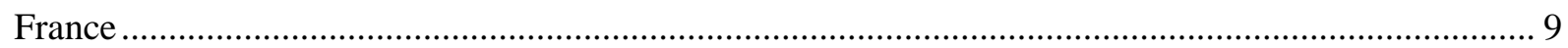

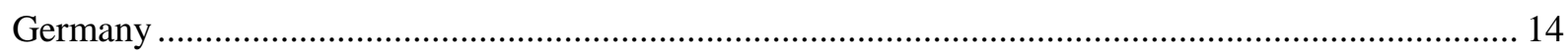

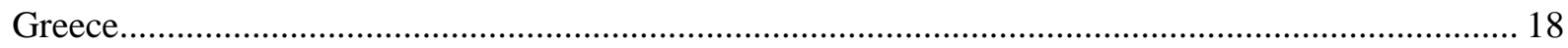

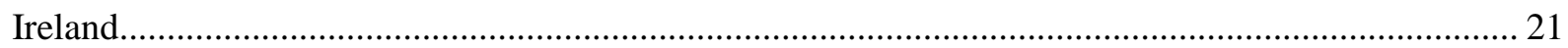

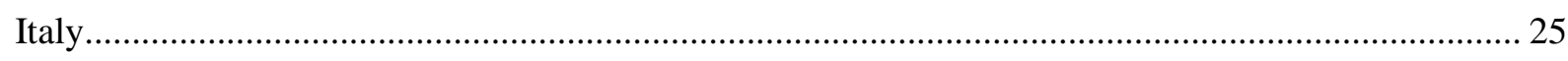

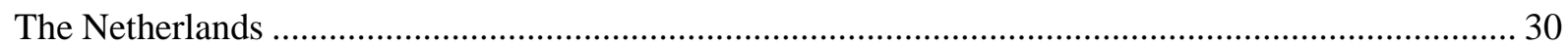

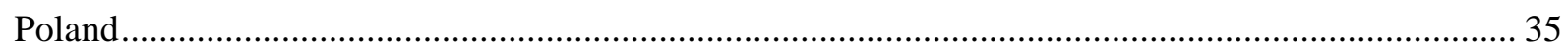

Spain

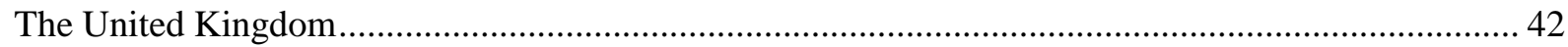

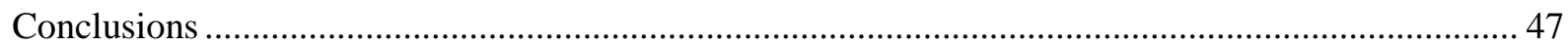





\section{Introduction}

Rónán Condon and Barend van Leeuwen

'We daily pour new wine into old bottles and apparently most of us never know the difference,1

\section{The starting point}

The examination of the development of Francovich liability in the national courts of the Member States remains a gap in our understanding of this hybrid remedy. ${ }^{2}$ To be sure, comprehensive studies exist that examine the development of Francovich liability at the level of the Court of Justice of the European Union ('CJEU') and these studies tell a particular story. ${ }^{3}$ However, the main assumption of this working paper is that how the Member State courts treat the conditions of liability can deepen this understanding by complementing the existing 'top-down' analysis with a 'bottom-up' perspective that examines how the conditions of liability are applied by national courts.

The defining characteristic of Francovich liability is its division of labour. The conditions of liability - conferral of a right, sufficiently serious breach, and causation - are autonomous of national legal concepts. ${ }^{4}$ However, the application of these conditions to the facts before the courts is a task for the respective Member State judiciary. In addition, procedural issues of importance as to the degree to which a claimant is compensated, such as tort limitation periods and the law on mitigation of damages, remain within the competence of national courts - subject to the rules on equivalence and effectiveness of European law. In both respects, this Working Paper wishes to explore the extent to which this has led to divergent or convergent interpretations of the conditions of liability and their limitation across Member State jurisdictions. However, particular focus has been placed on the conditions of liability, because it is submitted that in their interpretation we can locate the extent to which this European tort has been integrated into the tort law of the Member States, or whether to twist Leon Greene's analogy the old and new wines do not blend smoothly. ${ }^{5}$

Francovich liability surprised and confounded many when it emerged in the early nineties given the previous position of the CJEU in the area of liability of Member States for civil damages. ${ }^{6}$ The partition of competences had appeared clear. The CJEU occupied itself exclusively with identifying

${ }^{1}$ L Greene 'Tort Law Public Law in Disguise' 38 Tex. L. Rev. 259 (1959-1960), 265.

${ }^{2}$ P Giliker 'English Tort Law and the Challenge of Francovich Liability: Twenty Years On' (2012) L.Q.R. 541. Her examination of Francovich liability in UK law is illuminating and accords with what we found in our research to a large degree.

${ }^{3}$ T Tridimas, 'State Liability in Damages: Vingt Ans Apres' (unpublished, with author); T. Lock, 'Is private enforcement of EU law through State liability a myth? An assessment 20 years after Francovich', (2012) 49 CML Rev 1675. Lock's treatment of Francovich liability is less optimistic than Tridimas's.

${ }^{4}$ This became clear in Brasserie du Pecheur. The Court rejected the Member State submissions that the conditions could be equated with national conditions of liability, and emphasised the independent nature of the test of liability.

${ }^{5}$ P Giliker (n 2) Coined the phrase 'Eurotort' in the scholarly literature.

${ }^{6}$ Certain authors welcomed its introduction and found that it might be a useful palliative for problems in national law P Craig 'Once More into the Breach: The Community, the State and Damages Liability (1997) 113 LQR 67, others were less convinced see C Harlow 'Francovich and the Problem of the Disobedient State' (1996) 2 EurLK 199. In the first decade after the Francovich judgment much ink was spilt see $\mathrm{T}$ Tridimas The General Principles of EU Law (2nd edn. OUP 2006) 498, fn. 1 for a comprehensive list of the scholarly contributions. 
breaches of rights derived from European law, while it remained for the Member States to devise remedies to compensate individuals prejudiced by these breaches. Nowhere more was this approach typified than in Rewe which declared that the EU Treaty 'was not intended to create new remedies'. Francovich and Brasserie du Pecheur radically altered the landscape by providing an autonomous European tort law basis of recovery against the state when it has acted in breach of European law. Francovich made clear that the Treaty did in fact give rise to remedies, which were required on an effectiveness of European law and judicial cooperation justification. ${ }^{8}$ The CJEU, it is uncontroversial to say, discovered Francovich liability in a mood of judicial activism. ${ }^{9}$ Brasserie muddied the water somewhat as to the exact legal basis of Francovich liability, but nevertheless announced the arrival of an autonomous European tort - a 'Eurotort' in short. ${ }^{10}$ The CJEU, in particular, went considerably far to delineate the three conditions of liability. By far the most detailed analysis was devoted to the sufficiently serious breach condition, and, therefore, for the purposes of this Working Paper it is this condition that we examine in the greatest focus. To the extent, however, that other conditions of liability proved to be the question on which liability turned at the Member State level these conditions are also discussed. In addition, the CJEU stated that the tort was applicable to all branches of the state, the case-law of the court progressively expanded recovery from the administration to the legislature, and finally to the courts themselves in Köbler.

Francovich liability touches an area of law that has traditionally invoked controversy, namely, State liability. The degree to which the state can be held liable varies across Member State jurisdictions and is underpinned by different ideologies of the state. ${ }^{11}$ These have traditionally impacted on the extent to which the state, its agencies and agents, can be held liable in tort law. ${ }^{12}$ Despite the more liberal approaches to recovery against the administration, notably in France, in all jurisdictions it has been difficult if not impossible to recover against the legislature, and, in particular, the judicial branch of government. The reasons for these difficulties are legion. Notably, the balance between democracy and the rule of law features prominently as a reason against recovery, as does the doctrine of parliamentary supremacy which tends to underlie this issue. In more exact terms, the use of discretionary power by the government, the degree to which it is appropriate for a court to 'secondguess' through liability claims the use of such discretion, and the question of the appropriate allocation of resources are familiar arguments that tend to militate against the growing emphasis on the rights of claimants to tort law recovery. ${ }^{13}$ We might question, therefore, the extent to which these types of arguments prevail upon national courts in their interpretation of the conditions of Francovich liability and, in particular, their treatment of what constitutes a sufficiently serious breach.

The national reports that follow hopefully go some way to obtaining a better understanding of these issues. These reports are the culmination of a research process that began in early 2013. At that juncture, a research project was started at the European University Institute ("EUI") to investigate the impact of Francovich liability at the national level. The project is supervised by Professor Hans Micklitz (EUI) and Professor Takis Tridimas (King's College, London). It is funded by the ERC grant

\footnotetext{
${ }^{7}$ Case C 158/80 Rewe-Handelsgesellschaft Nord v Hauptzollamt Kiel [1981] ECR 1805.

${ }^{8}$ Francovich paras. 33-36.

${ }^{9}$ Tridimas (n 3) "Although in the Court's own postulation state liability is "inherent in the system of the Treaty", its origins lie in the effects-driven reasoning of the ECJ and its determination to turn "constitutional ideas into living truths." (Citations omitted)

${ }^{10}$ P Giliker (n 2).

${ }^{11} \mathrm{~J}$ Allison A Continental Distinction in the Common Law: A Historical and Comparative Perspective on English Public Law (OUP 2000).

${ }^{12}$ However, it has been argued that this difference is more a matter of form than substance. C Harlow 'Administrative Liability: A Comparative Study of French and English Law' (Ph.d thesis, 1979)

${ }^{13}$ Despite the tendency to view the remedy as sanction-based, the Court stated in AGM COS.MET that the remedy is a compensatory one.
} 
on European Regulatory Private Law. The ultimate aim of the project is to analyse to what extent Francovich liability has been integrated in the State liability regimes of the Member States and to see how effective it is as a remedy from the perspective of EU law.

In order to be able to undertake this analysis, a team of $\mathrm{PhD}$ researchers at the EUI, or connected to the EUI, was asked to search for case-law in which damages were claimed in national courts under the conditions for Francovich liability. In total, ten Member States have been included in the project. For each of these Member States the aim was to identify all cases in which Francovich liability was considered by national courts between 2000 and 2013. The precise methodology of the project will be set out in the next section of this introduction. It is important to note that the research at the national level provides just a starting point for the project. The aim is to identify trends and to select a number of issues or areas for further detailed analysis. As such, this Working Paper provides a rich source of information which will enable further analysis. Nevertheless, in the final section of the Working Paper we make some provisional conclusions based on the research to date, and propose further research questions that might assist in the future direction of our research.

\section{Methodology}

Researchers from a number of Member States with different legal traditions were asked to check national case-law databases for judgments in which the Francovich criteria for State liability were applied by national courts. In total, ten Member States were selected. These Member States were Finland, France, Germany, Greece, Ireland, Italy, the Netherlands, Spain, Poland and the United Kingdom. We analysed these particular Member States because we wanted to examine common law jurisdictions, the main civil law jurisdictions, at least one post-2004 accession Member State, and a Nordic jurisdiction. Our aim was not to obtain a complete picture of Francovich liability at the Member State level, but to obtain a representative sample to test the degree to which Francovich liability has been applied in Member State legal systems.

The online availability of judgments of national courts varies significantly across the Member States examined. In some Member States only judgments of the higher courts are available online. In other Member States, certain judgments of lower courts are reported, but not all of them. In certain jurisdictions, such as Greece or the United Kingdom, it is necessary to use private subscription databases to access judgments. Researchers were asked to use all online search databases available to them and to indicate which database(s) they used for their search. We asked researches to confine their search to judgments issued by the superior courts of the respective member states. In other words, issued by the (i) High Court (or equivalent), (ii) Court of Appeal (or equivalent) and (iii) Supreme Court (or equivalent). We confined the search in this manner to render it manageable in terms of the timeline envisaged for the project, and because the superior courts are those which interpret the law.

The reference period was the period from 1st January 2000 to 31st December 2013. The date of the judgment determined whether or not a case was included. However, some researchers (e.g. Ireland, Italy) included judgments from before the reference period in the context section of their research with a view to explaining the case-law. These results were not included in the statistical analysis which includes only judgments issued post-2000.

Researchers were asked to search broadly for relevant cases. They were asked to use their own experience of national databases to ensure that all relevant cases could be identified. We asked researchers to search using the following search terms:

- Francovich

- Substantive criteria: "sufficiently serious breach" or "conferral of right"

- Other important judgments, such as Brasserie du Pecheur/Factortame, Dillenkofer, Köbler 
These terms were meant to be non-exhaustive, and merely indicatory of what might disclose judgments. Researchers were asked to provide other search terms which they might have used and to explain why they used them. These explanations are furnished below in the methodological sections affixed to each Member State report. On the basis of this search exercise, researchers were asked to make a list with relevant judgments. Judgments were relevant if they discussed Francovich State liability as a 'real' possibility. In other words, it must have been discussed by the national court as a potential remedy in the particular judgment. This could be tested by analysing whether the national court discussed the substantive criteria for State liability. Mere passing references to the Francovich case were not sufficient.

For all relevant judgments, researchers were asked to complete an individual case form. For judgments in which different levels of courts had given a judgment, only one case sheet was completed and the final result was filled in the case form. Reference to the results of the lower courts was made in the factual and legal background.

Researchers were asked to provide the following information on the case form:

1. Case reference

2. Subject matter

3. Type of claimant (individual, business, collective)

4. Level of national court

5. Factual and legal background

6. Relevant conditions of liability

7. Other causes of action

8. Outcome

Researchers were asked to complete a short report for each Member State. These reports appear in the following section, along with an account of the methodology used, and the difficulties, if relevant, encountered by researchers. 


\section{Finland}

Mira Turpeinen (PhD Researcher, University of Turku, Finland)

\section{Statistics}

\begin{tabular}{|c|c|}
\hline Area of law & Number of cases \\
\hline Social security & 1 \\
\hline Taxation & 1 \\
\hline Total & 2 \\
\hline Court level & Number of cases \\
\hline Last instance & 2 \\
\hline Total & 2 \\
\hline Type of claimant & Number of cases \\
\hline Individual & 1 \\
\hline Business & 1 \\
\hline Total & 2 \\
\hline Outcome & Number of cases \\
\hline Claim successful & 1 \\
\hline Claim (ongoing) & 1 \\
\hline Total & 2 \\
\hline $\begin{array}{l}\text { Conditions of } \\
\text { liability considered }\end{array}$ & Number of cases \\
\hline Sufficiently serious breach & 2 \\
\hline Total & 2 \\
\hline
\end{tabular}

\section{Methodology}

The search was conducted using the following Finnish online up-to-date databases: Finlex and Edilex. The former is a free and public online database, owned by the Finnish Ministry of Justice, whereas the latter is a private legal information service produced by Edita Publishing Ltd. Both of these databases include the whole text of all the judgments of the Supreme Court and the Supreme Administrative Court that have been published in their annals. Moreover, they contain the texts of the judgments of the Courts of Appeal from 2004 onwards and summaries from the earlier judgments of the Courts of Appeal. Thus, the judgments (or, in the case of Courts of Appeal, at least their summaries) delivered in the period of $1^{\text {st }}$ January 2000 to $31^{\text {st }}$ December 2013 should all be available online.

For the search the following search terms were used: Francovich, Brasserie and/or Factortame and Köbler. In addition, I used the names of other State liability case-law. Finally, more substantive and 
broader terms were included such as "sufficiently serious breach", "conferral of rights", "State liability", "liability for damages and state" or even "European Union law". The terms chosen in the search followed the typical classification in the above-mentioned online databases which were also based on the previous cases on State liability.

\section{Context}

In Finland, the liability of public authorities has been an interesting and, to some extent, a questionable mixture of tort law and administrative law. In this paragraph, the national context regarding the liability of public authorities when they are exercising public power is briefly introduced. These observations are mainly based on doctoral research by Suvianna Hakalehto-Wainio ${ }^{14}$. The liability for non-contractual damages is primarily regulated in the Tort Liability Act (the Act), which also contains special provisions regarding the liability of public authorities or other entities when they exercising public power (Chapter 3 of the Act). According to Chapter 3, Section 2(1), the liability of public authorities is based on negligence and arises for injury or damage caused through an error or negligence in the exercise of public power. However, State liability differs from general tortious liability as the former is subsequently restricted by three provisions in Chapter 3 of the Act. The first restriction is found in Chapter 3, Section 2(3) of the Act which provides that liability arises only if the performance of the activity or task, in view of its nature and purpose, has not met the reasonable requirements set for it. In other words, this 'standard provision' mitigates the liability of public authorities in comparison to the general tortious liability inasmuch as it requires a higher level of negligence before the liability of public authorities arises. The second restriction can be found in the next section of the Act (Chapter 3, Section 4) which requires a prior appeal from the applicant. This means that one is entitled to damages only if the party has first appealed the decision by using all applicable legal remedies (after preliminary works including also possible an extraordinary appeal). The third restriction limits the liability of certain higher state organs, such as the Government, a Ministry, the Cabinet Office, a court of law or a judge. According to Chapter 3 Section 5 of the Act, an action for damages against the above-abovementioned state organs is not possible unless the decision has been amended or overturned or unless the person committing the error has been found guilty of misconduct or held personally liable in damages. Moreover, where a decision of an administrative authority has been appealed against the Government or the Supreme Administrative Court, no action in damages can be brought for injury or damage caused by the decision before it has become final.

As to the compatibility of the Finnish State liability regime with the state liability doctrine under EU law, one could conclude that all the restrictions above might be somewhat problematic and could be the subject of reform. In fact, the Ministry of Justice ordered a report and guidelines for a possible reform of the state liability rules in 2010. ${ }^{15}$ Although Hakalaehto-Wainio concluded in her report that the general regulatory framework for damages mainly coincides with the State liability regime of the EU, she nevertheless suggested that all the above-mentioned restrictions to the liability for public authorities should be repealed, especially with regard to Chapter 3 Section 5, which is in clear contradiction with the case-law of the CJEU on State liability. ${ }^{3}$ This section was already disapplied by the Supreme Court in the EVL case precisely for this reason (see below case 1). At the moment, the Ministry of Justice is considering whether it would amend the national State liability system based on the report, but no concrete legislative actions has been taken yet. In this respect, it seems that EU law is pushing a reform of the Finnish liability regime concerning the liability for public authorities, which has somewhat curiously emphasised the immunity, fluent public administration and freedom of actions of public authorities rather than the protection of the weaker party and allocation of resources within a

\footnotetext{
${ }^{14}$ Suvianna Hakalehto-Wainio, Valta ja Vahinko: Julkisen Vallankäyttäjän vahingonkorvausvastuu

15 Suvianna Hakalehto-Wainio, Julkisyhteisön vahingonkorvausvastuu (Tort Liability of Public Authorities) Ministry of Justice 59/2010. ${ }^{3}$ See ibid., at 73-81.
} 
asymmetric relationship between the individual and the state, as has been mentioned by HakalehtoWainio. ${ }^{16}$ As a final remark, one might note that the Finnish legislation does not exclude compensation for economic loss but imposes certain limitations on this type of damage. This means that damage for economic loss is only compensated if it has been caused by an act punishable by law or in the exercise of public authority, or in other cases, where there are especially weighty reasons for the same. This question arose also in a preliminary reference from Finland in the case $C 470 / 03 A G M-C O S . M E T^{5}$, but the Finnish legislator concluded that no legislative amendments were necessary because of the judgment.

\section{Narrative}

As only those cases in which Francovich liability was considered as a real potential remedy by national courts were to be included in this report, the cases in Finland were limited to two set of cases: the first case dealt with EVL related to car taxes on imported cars (KKO:2013:58) and the second case concerned social security issues (KHO:2012:104 and KHO:2012:105). The claimant in the first case was a business, albeit in a private capacity, and in the second case the claimant was an individual - a recipient of statutory social benefits. Both of the cases mainly focused on whether the breach was sufficiently serious. The applicant won the first case concerning EVL for used, imported cars and the state was liable to pay damages to the applicant. The second case is still pending because the Supreme Administrative Court decided to refer the case to the CJEU.

\section{Analysis}

Considering that there are only two cases in which the Finnish national courts thoroughly contemplated and applied Francovich conditions of liability, it is difficult to draw any clear conclusions about the Finnish liability case-law under EU law. However, in this paragraph a few observations will be made about both of the cases in order to help to demonstrate the underlying discourses and origins of the cases - especially with regard to a series of EVL decisions. However, firstly, this report will briefly address the question of whether State liability claims under EU law should be tried in civil or administrative courts. The CJEU has mainly left this question to be decided according to national procedural rules. In Finland, there is no legislation on this issue. Moreover, since the legal situation is unclear both for courts and academics, it is even more difficult for an individual to consider in which instance they should bring a claim for damages for the alleged breach of EU law by the state. As the Supreme Administrative Court concluded in the case KHO:2012:104, this may prove to be problematic as to the principle of effectiveness under EU law and the right to effective remedy inasmuch as the claim for damages under EU law is dismissed if a lower court considers that it has no jurisdiction on this issue.

The second issue concerning the Finnish State liability cases under EU law deals with the distinction between the revision of judgments and the claim for damages under EU law. This issue will be discussed in relation to the judgment of the Supreme Court (KKO:2013:58) that relates to a long and partly overlapping series of judgments that have raised confusion in the national legal context. The judgment of the Supreme Court (KKO: 2013:58) on ELV relating to car taxes is a result of a chain of judgments starting from case KHO:2002:85 in which the Supreme Administrative Court asked for a preliminary ruling from the ECJ (C-101/00 tulliasiamies ja Antti Siilin $\left.{ }^{17}\right)$. In its judgment the CJEU concluded that EVL would not be contrary to EU law per se provided that it would not have a discriminatory effect on imported, used cars in comparison with the amount of the residual tax incorporated in the value of a similar used car already registered in the national territory. However,

\footnotetext{
${ }^{16}$ See ibid., Hakalehto-Wainio (2008) at 49-70 and 413. ${ }^{5}$ Case C-470/03 AGM-COS.MET [2007] ECR I-2749.

${ }^{17}$ Case C-101/00 Tulliasiamies and Antti Siilin [2002] ECR I-7487.
} 
soon after the judgment it became clear that the legal situation remained ambiguous as regards the deduction of EVL at a later juncture in value added tax which was reserved only to those subject to VAT in Finland. This question was only indirectly raised in the above-mentioned preliminary reference Regardless of the general opinion of legal literature or the opinion of the Commission, the national authorities resorted to the interpretation as if the question of deduction was also resolved by the judgment in C-101/00 tulliasiamies ja Antti Siilin, which resulted in the judgment KKO 2002:85. The first claim for revision of this judgment was made in the case KHO:2006:95, in which the applicant also explicitly asked that a further preliminary reference on this issue should be made. Both of these claims were dismissed. At this time, the Commission had already noted that the right to reduce EVL was contrary to Article 90 EC. Some legislative amendments had been made in 2003 in Finland but they have not removed the debated issue. This was done not until 2009, when it was eventually decided that wrongly levied EVL should be reimbursed retrospectively from 2006. Finally, it was established in C-10/08 Commission v. Finland that the Finnish legislation as regards the qualified right to reduce EVL breached Article $90 \mathrm{EC}$. There have been many cases in which different applicants have sought a revision of the allegedly discriminatory EVL decisions. After the $C-10 / 08$ Commission v. Finland decision, the previous dismissal in the case KHO:2006:95 to revise the original car tax case was challenged in the cases KHO:2010:44 and KHO:2010:45, which were, in turn, challenged in the case KHO:2013:199. The latter case was filed after the successful State liability case discussed herein, but all of these revision claims were eventually dismissed by the Supreme Administrative Court. The subsequent satellite judgments show that the claimants have more than likely sought a revision of the allegedly discriminatory EVL decisions rather than filed a claim in damages under EU law. The reason might be Section 3(4) in Chapter 3 of the Tort liability Act requires a prior appeal (according to the preliminary work of the Act including also an extraordinary appeal) from the decision before a claim in damages is possible. This may prove to be unsatisfactory for the applicant who could be more successful with a claim for in damages under EU law as the Finnish court illustrate a clear resistance to annul the judgment even if this judgment 'sufficiently' breaches EU law. However, the recent State liability case in the Supreme Court on EVL relating to car taxes seems to represent some kind of paradigmatic shift in this respect. 


\section{France}

Hubert de Verdelhan (Legal Secrętary (Administrateur/Juriste), Chambers of Judge K. Jürimäe, Court of Justice of the European Union)

\section{Statistics}

\begin{tabular}{|c|c|}
\hline Area of law & Number of cases \\
\hline Agriculture & 7 \\
\hline Employment & 38 \\
\hline Environmental protection & 1 \\
\hline Free movement of goods & 10 \\
\hline Social security & 1 \\
\hline Taxation & 3 \\
\hline Health & 9 \\
\hline Discrimination & 60 \\
\hline Allocation of EU funds & 1 \\
\hline Competition & 1 \\
\hline Total & 131 \\
\hline Court level & Number of cases \\
\hline Last instance & 13 \\
\hline Court of Appeal & 118 \\
\hline Total & 131 \\
\hline Type of claimant & Number of cases \\
\hline Individual & 100 \\
\hline Business & 29 \\
\hline $\begin{array}{l}\text { Collective (group of individuals, } \\
\text { group of business, associations) }\end{array}$ & 2 \\
\hline Total & 131 \\
\hline
\end{tabular}




\begin{tabular}{|l|c|}
\hline \multicolumn{1}{|c|}{ Outcome } & Number of cases \\
\hline Claim successful & 20 \\
\hline Claim dismissed & 110 \\
\hline Preliminary ruling & 1 \\
\hline Total & 131 \\
\hline
\end{tabular}

\section{Methodology}

The databases used were Arineweb and Legifrance. The first one is provided by the Conseil d'État, the French administrative supreme court, and grants access to the case-law of this jurisdiction, together with the essential judgments rendered by the appeal courts. The second one is the main French public database for legal material, including statutes and rulings. It contains the judgments from appeal and supreme level courts, and some first instance judgments.

The terms used for the research were the followings: "Francovich"; "responsabilité" combined with "droit communautaire" or "droit de l'Union"; "responsabilite" combined with "directive", "règlement", "traité CE" or "traité FUE".

\section{Context}

State liability in the French legal system has several peculiarities. First, it is characterised by its autonomy from the general rules on liability provided in the Code civil ${ }^{18}$, which was decided by the French Tribunal des Conflict in the benchmark Blanco case in $1873^{19}$. State liability was thereby declared to be neither general nor absolute, but to obey to special rules. These special rules have been progressively established by the case-law of the Conseil d'État, the French Administrative Supreme Court. State liability under French law now concerns all the organs of the State, but operates under a variety of rules, mostly diverging in the requirement of fault (the activity of the State at stake being either under a regime of manifest breach, simple breach or strict liability). Notably, liability of the State for the performance of its judicial function was recognised in 1978 in Darmont ${ }^{20}$; however, it was initially limited to procedural aspects (excessive length of the proceedings, for instance ${ }^{21}$ ). Liability of the State for harm caused by a statute of the parliament ("loi") has been possible since the ruling of 1938 Société "La Fleurette, ,22 , in case of "serious" and "special" harm, on the ground of a breach of equality in relation to public burden. However, the Conseil d'État had established in its ruling Nicolo that it would not rule on the liability of the state acting in its legislative function ${ }^{23}$. The interpretation of EU law before French courts has challenged this approach. The first case related to the incompatibility of an administrative act with EU law, Société Arizona Tobacco Products et SA Philip Morris France ${ }^{24}$, concerned a regulation adopted on the basis of a statute contrary to EU law. The Conseil d'État chose to set aside the statute as incompatible with EU law and held the State liable on the ground that the regulation had been adopted without a legal basis. The source of the liability

\footnotetext{
* The views expressed in this report are strictly personal.

${ }^{18}$ Code civil, articles 1382 to 1386.

${ }^{19}$ Tribunal des conflits, 8 February 1873, Blanco, rec. 00012.

${ }^{20}$ CE, 29 December 1978, Darmont, Dalloz 1979, p. 278, note Vasseur.

${ }^{21}$ CE, 28 June 2002, Magiera, rec. 239575.

${ }^{22}$ CE, 14 January 1938, Société anonyme des produits laitiers “La Fleurette”, rec. 51704.

${ }^{23}$ CE, 20 October 1989, Nicolo, rec. 108243.

${ }^{24}$ CE 28 February 1992, SA Philip Morris France, rec. 87753.
} 
was, therefore, a purely national breach of the duty of legality. In its Gardedieu ${ }^{25}$ ruling in 2007, the Conseil d'État recognised the possibility of the State being liable for a statute incompatible with its international obligations. While the case concerned a breach of rights guaranteed by the European Convention on Human Rights, its broad scope of application included EU law. Eventually, in 2008, in Gestas $^{26}$ the Conseil d'État acknowledged Köbler and confirmed the essence of its wording, thus opening up the possibility of State liability for the performance of its judicial function - not only on procedural grounds, but also where the substance of a definitive ruling amounts to a manifest breach of EU law. Both with regards to the State function subject to liability rules and to the conditions for liability (manifest breach, causation and harm, with the exception to the Gardedieu type of liability, which appears to be a strict liability/no-fault regime), French law complies with EU law. Although State liability was already broadly construed, it can be said that Francovich and Köbler resulted in the extension of the scope of liability of the State, as demonstrated by Gestas and Gardedieu.

\section{Narrative}

In the relevant time period, namely 2000-2013, 131 cases involving questions related to liability of the State for breaches of EU law were found. Only 20 of these were successful claims, although some of the dismissed claimants were compensated on other grounds (such as a breach of ECHR ${ }^{27}$, or of national law $^{28}$ ).

Francovich liability was invoked in very different fields, ranging from free movement of goods to employment law and agricultural funds. Notably, two cases ${ }^{29}$ present a factual background similar to the one at stake in Francovich, related to guarantee funds for wage claims in case of insolvency of the employer.

As for the State function involved, most of the cases concerned a failure of the administration to act in compliance with EU law. Several cases concerned a failure of the legislator to comply with EU law (Bleitrach, Leone ${ }^{30}$ ); one case, Société Phytoservice II $^{31}$, concerned Köbler-style liability of the State in the performance of its judicial function.

\section{Analysis}

Most of the time, the appeal courts and the Conseil d'État upheld the existence of a breach of EU law where it had already been established by a prior judgment of the CJEU (this can be seen for instance in Société Bruyagri", Association "Halte aux marées vertes" "33, Société $\left.C R T^{34}\right)$. However, in Association

${ }^{25}$ CE, 08 February 2007, Gardedieu, rec. 279522.

${ }^{26}$ CE, 18 June 2008, Gestas, RFDA 2008.755, conclusions de SALINS.

${ }^{27}$ See, for instance, CE, 37 July 2009, Société Ulysse SAS, rec. 316525.

${ }^{28}$ See, for instance, CE, 22 October 2010, Bleitrach, rec. 301572.

${ }^{29}$ CA Marseille, 21 February 2011, 09MA00892, 09MA00706.

${ }^{30}$ CA Lyon, 24 September 2013, Leone, 12LY02990. Leone concerned the compatibility of a certain pension benefit attributed to public servants parenting children with the principle of non-discrimination on ground of sex. The Conseil d'État, facing a flow of proceedings concerning said issue, ruled this benefit to be compatible with article 141 TCE. However, the appeal court in Leone chose to refer the issue to the CJEU, which declared this benefit to amount to an indirect discrimination on ground of sex, contrary to article 141 TEC (ECJ, 17 July 2014, Leone and Leone, C-173/13).

${ }^{31}$ CE, 27 March 2013, Société Phytoservice, rec. 351528. The Conseil had to establish whether or not it had committed a manifest breach of EU law in its previous ruling Société Phytoservice (CE, 30 December 2009, rec. 303506) where it ruled that the State was not liable for maintaining a prior authorisation regime incompatible with EU law.

${ }^{32}$ CE, 24 July 2009, Société Bruyagri, rec. 296140. 
"Halte aux marées vertes", the Court of Appeal went beyond the mere acknowledgment of the finding of an infringement by the CJEU by stating that the alleged failures of the State had to be considered "important" and "numerous", thus amounting to a manifest breach. It also referred to prior judgments of the CJEU to establish that there was no manifest breach (Société Ulysse and Société Cargill ${ }^{35}$ ).

In relation to the branches of government, it appears that the Conseil d'État seems reluctant to find a manifest breach where the judicial or legislative function of the State is at stake. In Société Phytoservice II, the Conseil d'État rejected without in-depth reasoning the claim that it had committed a manifest breach in its ruling Société Phytoservice, even though the test it applied to reject causality seemed overly strict, and it ignored the fact that in its Société Bruyagri ruling, delivered shortly before, it adopted a more lenient approach in that respect, in a situation very similar to the one at stake in Société Phytoservice. In Bleitrach, it interpreted the requirements of the Employment Equality Framework Directive ${ }^{36}$ as regards the deadline for making all working places suitable for disabled people to establish that the State had not breached EU law when postponing the compliance of all public premises to said requirements, without sending the issue to the CJEU for a preliminary reference. This tendency is also visible in the Société Sirio ${ }^{37}$ ruling, in which the appeal court ruled that a tax incompatible with EU law amounted to a failure of the legislator (who adopted the principle of the tax) to respect its international obligations (Gardedieu-style). However, on appeal, the Conseil d'État, rejected the approach of the appeal court and ruled that the breach was committed by the administration when adopting the implementing regulation on the tax.

As regard causation, the Conseil d'État, in principle, applies a rather strict test ("causalité adéquate") which sometimes leads to harsh results - perhaps questionable from the perspective of EU law. In Société Phytoservice, the claimant sought compensation partially for the harm he suffered from fiscal redress after he had imported goods on the French market without authorisation. Although the French authorisation mechanism did not comply with EU law, the Conseil ruled that there was no causal link between the incompatibility of the authorization procedure and the harm, since the company never asked for any authorisation from the State in the first place. Interestingly, this harsh assessment of causation had been rejected shortly before in Société Bruyagri, where the Conseil had ruled that there was causation between the harm of the claimant and the breach of the State - the failure to set in place an authorisation procedure compliant with EU law - notwithstanding the fact that the claimant had never applied for an authorisation to import. A striking example of the application of the adequate causation test can also be found in Lafaye de Michaux ${ }^{38}$, where the appeal court denied causation between the fault of the administration - which had unlawfully retained $20000 €$ of EU funds allocated to a company for a development project - and the bankruptcy of this company, on the ground that the expenditures of the company with respect to the project were higher than the sum retained, and it had not demonstrated how it intended to pay the rest of the said expenditures. Camuset ${ }^{39}$ provides, in addition, a good example of the strict interpretation of causation: while the claimant alleged that his employer, a municipality, would have converted his numerous and consecutive fixed term contracts into an indefinite duration one if the legislator had correctly transposed the Directive on fixed-term work $^{40}$, the appeal court considered that the harm was suffered by the claimant when his contract did

(Contd.)

${ }^{33}$ CA Nantes, 1 December 2009, Association “Halte aux marées vertes", rec. 324925.

${ }^{34}$ CE, 3August 2011, Société CRT France International, rec. 304838.

${ }^{35}$ CE, 31 July 2009, Société Cargill France, rec. 324925.

${ }^{36}$ Council Directive 2000/78/EC of 27 November 2000 establishing a general framework for equal treatment in employment and occupation (OJ L 303, p. 16).

${ }^{37}$ CE, 3 August 2011, Société Sirio Antenne SRL, rec. 322041.

${ }^{38}$ CA Marseille, 17 November 2009, Lafaye de Michaux, 07MA00055.

${ }^{39}$ CA Douai, 9 June 2011, M. Camuset, 10DA00077.

${ }^{40}$ Council Directive 1999/70/EC of 28 June 1999 concerning the framework agreement on fixed-term work concluded by ETUC, UNICE and CEEP (OJ L 175, p. 43). 
not get renewed rather than when the legislator failed to transpose the Directive. Such a strict test of causation makes it almost impossible for a claimant to obtain compensation for a failure of the legislator to comply with EU law, as another cause for the harm could always be established, attributing the failure to another branch of the State.

The Conseil d'État adopted a broad view of the harm requirement. In Société CRT, it admitted the principle that the loss of sale constitutes harm, while requiring concrete evidence that the loss was really consecutive to the breach of the state and not to external factors such as market tendencies. Notably, as regards exploitative loss, both the administrative courts and the Conseil d'État usually use a counterfactual scenario, assessing whether the turnover of a claimant company would have accrued if the State had not breached EU law (see for instance Société prodal ${ }^{41}$ ). However, some appeal courts have shown themselves to be particularly lenient with regards to the demonstration of harm by not requiring the claimant to actually "show figures", but by rather assessing independently the harm on the sole ground that the breach of EU law had made the activity of the claimant "more difficult" (see Société Aprochim ${ }^{42}$ ). On the contrary, some appeal courts required actual evidence that the breach had hindered the activity of the claimant, and to what extend it had done so (Société "la biomécanique intégrée $e^{, 43}$.

Finally, on numerous occasions the appeal courts and the Conseil d'État chose not to refer preliminary rulings to the CJEU in cases where its interpretation of EU law was more than dubious. The compatibility of the French legislation on pensions, eventually tackled and referred in Leone, is a striking example.

\footnotetext{
${ }^{41}$ CA Paris, 11 July 2007, Société Prodal, 06PA01658.

${ }^{42}$ CA Nantes, 3 December 2007, Société Aprochim, 06NT01418.

${ }^{43}$ CA Paris, 29 November 2006, Société “la biomécanique intégrée”, 03PA01140.
} 


\section{Germany}

Maria Jose Schmidt-Kessen (PhD Researcher, European University Institute)

\section{Statistics}

\begin{tabular}{|c|c|}
\hline Area of law & Number of cases \\
\hline Administrative & 2 \\
\hline Agriculture & 3 \\
\hline Banking & 4 \\
\hline Contract & 2 \\
\hline Criminal & 1 \\
\hline Corporate & 1 \\
\hline Employment & 33 \\
\hline Free movement of goods & 3 \\
\hline Free movement of persons & 1 \\
\hline $\begin{array}{l}\text { Free movement of services/ } \\
\text { establishment }\end{array}$ & 22 \\
\hline Free movement of workers & 1 \\
\hline Health & 2 \\
\hline IP & 1 \\
\hline Taxation & 5 \\
\hline Trade & 1 \\
\hline Total & 82 \\
\hline Court level & Number of cases \\
\hline Last instance & 48 \\
\hline Court of Appeal & 20 \\
\hline First instance & 14 \\
\hline Total & 82 \\
\hline Type of claimant & Number of cases \\
\hline Individual & 43 \\
\hline Business & 38 \\
\hline $\begin{array}{l}\text { Collective (group of } \\
\text { individuals, group of } \\
\text { businesses, associations) }\end{array}$ & 1 \\
\hline Total & 82 \\
\hline
\end{tabular}




\begin{tabular}{|l|c|}
\hline \multicolumn{1}{|c|}{ Outcome } & \multicolumn{1}{c|}{ Number of cases } \\
\hline Claim successful & 32 \\
\hline Claim dismissed & 50 \\
\hline \multicolumn{1}{|c|}{ Total } & $\mathbf{8 2}$ \\
\hline Reason for dismissal of claim & Number of cases \\
\hline $\begin{array}{l}\text { Procedural lack of jurisdiction } \\
\text { to hear state liability claim }\end{array}$ & 2 \\
\hline $\begin{array}{l}\text { No last instance (in case of } \\
\text { Köbler-type claims) }\end{array}$ & 2 \\
\hline No sufficiently serious breach & 36 \\
\hline No conferral of individual right & Total \\
\hline No causal link & 5 \\
\hline
\end{tabular}

\section{Methodology}

To conduct the search of German case-law in which Francovich liability was claimed Juris, an online database, was used. ${ }^{44}$ It is a general legal database used by German practitioners, comparable to LexisNexis in the US or Dalloz in France. In terms of German case-law, it contains cases from regional courts, higher regional courts (appeal courts) and federal courts (last instance). However, not all judgments are reported. The search was conducted mainly from 1 January 2000 to 31 December 2013.

The search terms used were

1. "Francovich" (98 hits retrieved with the application of the filter of German regional and federal courts only)

2. "Factortame" ( 74 hits retrieved with the application of the filter of German regional and federal courts only)

3. Combination of "Köbler" and "Haftung" 45 (65 hits retrieved with the application of the filter of German regional and federal courts only).

Out of the total of 237 hits retrieved resulted 82 cases discussing the Francovich liability conditions (counting a judgment only once which went through several instances).

While these search terms already resulted in a high absolute number of results, I expect there to be still many more cases that the above search did not retrieve. While reading and comparing the judgments, especially the same judgments at different instances, it became clear that German courts do not necessarily refer to the same CJEU's case-law when discussing Francovich liability (this type of liability is referred to by German courts as "gemeinschaftsrechtlicher/unionsrechtlicher Staatshaftungsanpruch" and is clearly differentiated from the German State liability regime which is referred to as "Amtshaftungsanspruch (nach deutschem Recht)"). I expect that searching with other CJEU cases as search terms as e.g. "Brasserie du Pêcheur" or "Dillenkofer" would have delivered

\footnotetext{
${ }^{44}$ Juris - Das Rechstportal

www.juris.de.ezproxy.eui.eu/jportal/portal/t/afm/page/homerl.psml?cmsuri=\%2Fjuris\%2Fde\%2Fstartseite $\% 2$ Fstartseite.jsp (last visited 2 July 2014)

${ }^{45}$ Haftung means "liability" in German
} 
further cases from the ones found so far. Furthermore, some case reports do not refer to EU law at all when analysing Francovich liability claims, but only to German commentaries (e.g. the standard commentary on the EU Treaties, EUV / AEUV by Callies and Ruffert). Finding all these cases would mean to search e.g. with the search term "Staatshaftung" only (which yields 1660 hits for the relevant time frame).

\section{Context}

Francovich has been accepted in German case law as an autonomous basis for State liability (gemeinschaftsrechtlicher/unionsrechtlicher Staatshaftungsanspruch), in addition to the German doctrine of State liability (Amtshaftungsanspruch on the basis of $\S 839$ para. 1 sentence 1 BGB (civil code) in conjunction with Art. 34 GG (German basic law)). One of the most important differences is that liability is construed strictly under EU State liability, i.e. without a fault requirement, whereas the German State liability doctrine requires fault (Verschulden) of the state official in question.

Concerning Köbler-type liability for a breach of EU law by courts, the German law of State liability is also different. Under certain circumstances, judges from any instance can be made liable under German law (again on the basis of $\$ 839$ BGB). However, the requirement is, in light of the principle of judicial independence, a qualified form of fault (intention/Vorsatz). Furthermore, there will be generally no liability when a court decision was handed down after deliberation with other judges. This means that whenever a decision is taken by a senate with several members there will be no liability for individual judges under German law (BGH III ZR 9/91).

State liability under EU law supplements German State liability law, because it does not include a fault requirement. Consequently, it would appear easier for claimants to receive damages under EU State liability law than under German liability law.

\section{Narrative}

The search using the above methodology yielded a total of 82 cases that discussed the conditions of EU State liability. About half of the cases (48 cases) were final instance cases, followed by 20 appeal cases and 14 first instance cases. The claimants were mostly individuals (in 43 cases) and undertakings (in 38 cases). A very high number of claims were brought in the area of employment (33 cases) and freedom of services (22 cases). In approximately one-third of the cases the claimant was successful (32 cases). The most frequent reason for dismissing a State liability claim was that there was no sufficiently serious breach of EU law (in 36 cases out of a total of 50 dismissed cases). This was, in particular, the case when the breach had occurred before the CJEU had found that there had been a breach of EU law.

\section{Analysis}

Overall, Francovich has been well received by German courts. Courts at all levels seem to handle the Francovich criteria comfortably. The case-law shows a tendency, however, against awarding damages. In particular, German courts have been reluctant to award Francovich damages in cases where a breach of EU law had not (yet) been established by the CJEU. As a rule, in these cases, the sufficiently serious breach-condition was found not be fulfilled because Member States had a wide margin of discretion when implementing EU law, or because it was only after clarification by the CJEU that it had become apparent that there had been a breach of EU law. In judgments in which there was existing German case-law confirming the compatibility with EU law prior to the CJEU's judgment establishing a breach, the courts were especially reluctant to find a sufficiently serious breach of EU law (e.g. BVerwG, 8 C 20/12). Therefore, in circumstances where there is no blatant breach - such as a complete failure to implement a directive - German courts seem to be prepared to find a sufficiently serious breach only if there has been a prior judgment of the CJEU which found a breach. This 
practice could run counter to the Francovich jurisprudence as explained by the CJEU in Danske Slagterier, Brasserie du Pêcheur and Dillenkofer: In these judgments it was established that the reparation of loss or damage cannot be made conditional on the requirement that there has been a prior finding by the CJEU of an infringement of EU law attributable to the state.

The two most obvious patterns are the high number of cases decided at last instance (48 cases: more than half) and the two areas of law, employment and freedom of services, in which most cases were decided. The high number of employment cases is related to the high number of cases decided at last instance. Of the 33 employment cases, almost all were brought by firefighters who had worked overtime. 22 of these cases were decided in parallel proceedings by the Federal Administrative Court $(B V e r w G)$ after the CJEU had held in $F u \beta$, on the basis of the Working Time Directive, that the relevant German law was contrary to the Directive. In all the firefighter cases, State liability was established and damages were awarded. The high number of cases in the area of freedom of services (22 cases) concerned the laws of the Länder which prohibited the provision of sport betting and gambling services (also over the Internet) by private service providers. The Land monopoly on sport betting and gambling services was challenged after the CJEU's judgment in Carmen Media and other cases on gambling services, leading, inter alia, to 10 parallel cases decided by the BVerwG. In all these cases State liability was denied, because the Member States' margin of discretion had been wide in this area and the legal situation under EU law had been unclear before the CJEU's judgments. There was, therefore, no sufficiently serious breach of EU law according to all German courts. 


\section{Greece}

Mihalis Decastros (PhD Researcher, European University Institute)

\section{Statistics}

\begin{tabular}{|c|c|}
\hline Area of law & Number of cases \\
\hline Education & 1 \\
\hline Property (expropriation) & 1 \\
\hline Employment & 2 \\
\hline Total & 4 \\
\hline Court level & Number of cases \\
\hline First instance & 4 \\
\hline Total & 4 \\
\hline Type of claimant & Number of cases \\
\hline Individual & 4 \\
\hline Total & 4 \\
\hline Outcome & Number of cases \\
\hline Claim successful & 2 \\
\hline Claim dismissed & 2 \\
\hline Total & 4 \\
\hline Reason for dismissal of claim & Number of cases \\
\hline No conferral of individual right & 1 \\
\hline No damage & 1 \\
\hline Total & 2 \\
\hline
\end{tabular}

\section{Methodology}

In Greece, for privacy reasons, court judgments are not available online for everyone to access. There are, however, subscription-based databases that judges and practitioners use in order to access judgments online. Therefore, for my research, I used the two main databases, one privately managed and the other one operated by the Athens Bar. The links to these websites are the following:

1. https://lawdb.intrasoftnet.com

2. http://www.dsanet.gr

It should, however, be noted that the most important decisions of the Supreme Administrative Court ("Conseil d'Etat") are usually available online under a "recent important judgments" section. 


\section{Context}

Greek Law, until 1946, did not have any statutory basis which regulated the conditions under which State liability to pay damages for harm could arise. There was some case law on the matter, but the issue remained unsettled. This vague state of affairs was later clarified by the introduction of the new Civil Code of 1946, which provided for State liability under Articles 104-106 of its "Introductory Law".

The Articles provide for the existence of 5 conditions for State liability. First of all, there must have been an act or omission committed by an organ of the State (widely interpreted, since this would cover the category of "legal persons under public law" that referred to most public companies existing at the time and for many more decades). Secondly, the act must have been committed by the relevant State organ in the exercise of public authority. Thirdly, this aforementioned act must be unlawful. Interestingly, for the purposes of this research, it is widely accepted that the element of illegality is fulfilled when there is a violation of EU Law (since under Article $28 \$ 1$ of the Constitution the widely accepted principles of international law along with the treaties ratified by the State automatically become part of domestic law and supersede any other incompatible domestic law already in place). It is now also accepted (after some controversy that persisted for years - until the late eighties, early nineties) that even the Parliament itself (as a state organ) can commit an unlawful act merely through its legislative activities (if the relevant law violated the Constitution, EU Law or other treaties incorporated by virtue of Article $28 \S 1$ of the Constitution). Fourthly, the illegality cannot be based on the violation of a provision that was intended to protect the general public interest. Finally, the claimant must have suffered damages. The literature and case law have also recognised the existence of an additional implicit condition, namely the existence of a causal nexus between the damage and the unlawful act.

It is clear that the conditions for State liability under Greek law are relatively similar to those under EU law. However, the most important difference is that there is no requirement of a sufficiently serious breach. Therefore, it seems that the requirements under Greek law are more favourable than under EU law. This raises interesting questions regarding the relationship between the EU and domestic law remedies for State liability, which will be discussed below.

\section{Narrative}

In total, four relevant cases were found. Half of the cases were brought in the field of employment law. In all these cases, Francovich liability was usually not the main claim but an additional basis for claiming damages. The other two cases concerned issues of education (mutual recognition of employment rights) and expropriation of property. All the cases were individual claims.

Two of the cases were successful, while the other two were unsuccessful. In the first of the unsuccessful cases, the reason was that the Court was not satisfied that EU law had conferred direct rights on individuals. In the other case, the Court found that the claimant had not suffered damages.

\section{Analysis}

Greek courts have, in general, been very receptive to the idea of State liability for violations of EU law and have to a large extent incorporated the relevant jurisprudence of the CJEU into their reasoning.

The first main and probably the most interesting conclusion we can draw is that the Greek courts do not perceive Francovich liability as a completely separate legal basis on which individuals can base claims for compensation. On the contrary, they seem to conflate the relevant notion of compensation for unlawful acts and omissions of the state under domestic law with the similar notion of Francovich 
liability. In that context, they always refer to the Francovich conditions, but they seem to perceive them as an additional basis for the unlawfulness of the state's conduct. If they are satisfied that illegality is present, they then proceed to examine the rest of the conditions set out under Article 105 of the Greek Introductory Law of the Greek Civil Code (e.g. existence of damage, causal nexus etc). In that context, the Greek courts do not consider the Francovich case-law as introducing a new remedy under domestic law. They rather incorporate the substantive elements of the case-law in their interpretation of Article 105 but, at the end of the process, the remedy awarded is a domestic law remedy.

Furthermore, another interesting observation is that the courts are unwilling to accept that a claim for compensation can be based on the allegation that the courts themselves have failed to interpret and implement EU law properly (case 17346/2008). Moreover, a possibly more minor conclusion is that the courts consistently consider the ECHR as part of primary EU law and do not hesitate to award compensation on the basis of that (despite the fact that this unnecessary since, according to the Greek Constitution, the ECHR is at a higher normative level than normal domestic law).

A final conclusion that can be drawn is that whenever there has been a CJEU judgment condemning Greece for the failure to incorporate or implement a directive properly, the courts always take that into account and are more willing to award compensation to individuals. 
R. Condon and B. van Leeuwen with M. Dekastros, L. Díez Sánchez, F. della Negra, P. Pałka, M. J. Schmidt-Kessen, M. Turpeinen and H. de Verdelhan

\section{Ireland}

Rónán Condon (PhD Researcher, European University Institute)

\section{Statistics}

\begin{tabular}{|c|c|}
\hline Area of law & Number of cases \\
\hline Agriculture & 2 \\
\hline \multicolumn{2}{|l|}{ Asylum and immigration } \\
\hline Employment & 1 \\
\hline \multicolumn{2}{|l|}{ Environmental protection } \\
\hline \multicolumn{2}{|l|}{ Free movement of goods } \\
\hline \multicolumn{2}{|l|}{ Social security } \\
\hline \multicolumn{2}{|l|}{ State aid } \\
\hline \multicolumn{2}{|l|}{ Taxation } \\
\hline Health & 1 \\
\hline Cross-border cooperation & 1 \\
\hline Total & 5 \\
\hline Court level & Number of cases \\
\hline \multicolumn{2}{|l|}{ Last instance } \\
\hline \multicolumn{2}{|l|}{ Court of Appeal } \\
\hline First instance & 5 \\
\hline Total & 5 \\
\hline Type of claimant & Number of cases \\
\hline Individual & 2 \\
\hline Business & 3 \\
\hline \multicolumn{2}{|l|}{$\begin{array}{l}\text { Collective (group of individuals, } \\
\text { group of businesses, } \\
\text { associations) }\end{array}$} \\
\hline Total & 5 \\
\hline Outcome & Number of cases \\
\hline Claim successful & 1 \\
\hline Claim dismissed & 4 \\
\hline Total & 5 \\
\hline
\end{tabular}




\begin{tabular}{|l|c|}
\hline \multicolumn{1}{|l|}{ Reason for dismissal of claim } & Number of cases \\
\hline $\begin{array}{l}\text { Procedural (incl. limitation } \\
\text { period) }\end{array}$ & \\
\hline No breach of EU law & 2 \\
\hline No sufficiently serious breach & 0 \\
\hline No conferral of individual right & \\
\hline No causal link & 2 \\
\hline & Total \\
\hline
\end{tabular}

\section{Methodology}

I used westlaw.ie and bailii.org to search for Francovich liability judgments. I examined judgments both prior to 2000 and post-2000, but for the purposes of analysis restricted statistical entry to the post-2000 judgments. The pre-2000 judgments assisted in establishing context. The main search terms used were, 'State liability', 'sufficiently serious breach', and 'conferral of a right'. In addition, a number of leading cases were used as search terms, such as 'Francovich', 'Brasserie', 'Köbler', 'Brinkmann', and so on. From an initial find of 32 judgments, these were filtered in accordance with our 'relevance' requirement.

\section{Context}

The starting point for an analysis of Francovich liability in Irish law is Carroll J's statement in Robinson v Minister for Social Welfare [1995] E.L.R. 86. In that judgment Carroll J. distinguished between breach of statutory duty, breach of the duty of care, breach of a constitutional duty and Francovich liability:

In my opinion, the wrong committed by the State in continuing the discrimination by failing to fully implement the Directive is a wrong arising from Community law which has domestic effect. It is not a breach of constitutional rights; it is not a breach of statutory duty and it is not a breach of the duty of care. It is a breach of duty to implement the Directive and it approximates to a breach of constitutional duty. Every type of action which would be available in the national domestic law to ensure the observance of national law is available to ensure observance of the Directive once it took on the mantle of direct effect.

It might be surmised, therefore, that Irish courts have been more careful than their English colleagues to conceptually distinguish Francovich liability as a distinct basis of liability and have foregone the temptation to elide it with existing grounds of recovery. However, this does not mean that Francovich claims have appeared often before the superior courts. To date, we have found only one example of a successfully litigated claim based on Francovich liability.

\section{Narrative}

To date, only five cases were litigated on the basis of Francovich liability. Two claims related to the field of agriculture, one to employment, one to health, and one to the subject of cross-border cooperation. A number of other judgments have referred to Francovich in passing but do not meet the relevance requirement following the methodology of our study. 


\title{
Analysis
}

\author{
Sufficiently Serious Breach
}

\section{Pre-2000}

The Irish courts have not extensively treated the relevant factors enumerated in Brasserie for a breach to be treated as sufficiently serious. ${ }^{46}$ Dublin Bus $v$. MIBI proposed to apply those factors in a 'global fashion' rather than conjunctively or disjunctively. It is accepted that internal arguments (internal to the national constitution) about the distribution of powers are not relevant (O'Reilly). In Maxwell $v$ Min for Agriculture, McCracken J. stated that he was without guidance as how to apply the criteria, despite the factors enumerated in Brasserie. In Emerald Meats $v$ Min for Agriculture the Supreme Court accepted that male fides did not have to be proven in a State liability case.

\section{Post-2000}

Two cases since 2000 have applied the Francovich criteria; the first was Rooney $v$ Minister for Agriculture in the High Court. Laffoy J. accepted if arguendo conditions 1 and 2 (conferral of a right, sufficiently serious breach) were fulfilled, as a matter of causation the defendants were not liable. This was because the learned judge held that it was the plaintiff's conduct that caused his loss. No reference was made to the CJEU's jurisprudence for this conclusion (for example, no reference to the discussion of causation in Brinkmann). Second, in the far more extensively argued Bupa v Rev Commissioners (2013) (HC) case, Cooke J. applied the Bergaderm interpretation of Francovich. The learned judge stressed the complexity of the area, the positive steps taken by the Minister to obtain advice and consult the Commission, and the absence of actual loss, as reasons as to why the loss was not sufficiently serious. The last point overlapped with his comments on causation. In effect, the claimant did not suffer losses because he withdrew from the market before the impugned scheme (in breach of EU law) could be implemented against him. In consequence, Cooke J.'s argumentation relied partly on causation and partly on circumstances of mitigation to refuse liability. Therefore, of the two cases that dealt with Francovich both dismissed the claim on the basis of the conduct of the parties which was subsumed under the heading of causation, with sufficiently serious breach assumed for the sake of argument (Rooney), or, the breach was deemed not to sufficiently serious (Bupa).

In Davis Joinery v Companies Acts (2013) (HC) Laffoy J. held that in light of Francovich II it was unlikely that the plaintiff would succeed, although clarification was required. Instead of making a preliminary reference, Laffoy $\mathrm{J}$. found a national law mechanism to obtain a remedy for the plaintiff. The sufficiency of the breach, or otherwise, was not discussed.

In Ogieriakhi v Min for Justice (2013) (HC) Hogan J. made a preliminary reference to the CJEU. In Ogieriakhi the plaintiff, a Nigerian, who was dismissed from his position at An Post (the postal service), argued that he was entitled to the protection of Directive 2004/38/EC specifically invoking his right to residence based on the rights of his spouse, a Union citizen. The facts of the case complicated matters because he did not reside with his wife for the relevant reference period, although he remained legally married. Hogan J. made clear that, in particular, Brasserie and ex parte BT indicate that a relevant factor regarding Francovich is the clarity of the Directive before referring the case to the CJEU. It will be recalled that this goes to whether a right is conferred and whether a breach is sufficiently serious.

In the only case in which the claimant succeeded on the basis of Francovich there was no discussion of the Francovich criteria. Figary concerned a breach of statutory duty in which the statutory duty was

\footnotetext{
${ }^{46}$ O'Reilly 'The Private Enforcement of European Community Law in the Irish Superior Courts' (2009) DULJ 1 .
} 
created on foot of a directive. The judge awarded damages against the state but did not discuss the relevant criteria at all, treating Francovich as if it were strict liability i.e. once a breach, then liability follows automatically.

\section{Conclusion}

By way of provisional conclusions, it is submitted that in the current state of the law it is difficult to speak of an Irish approach to Francovich liability. The number of cases that have reached the Superior Courts is low in absolute terms, and the treatment of the remedy has at times been terse. What is clear is that in those cases which have examined the doctrine more thoroughly, causation plays an important role as a control mechanism, and in the recent case-law there appears to be an attempt by Justice Hogan to create a bridge between Francovich liability and fundamental rights protection. 
R. Condon and B. van Leeuwen with M. Dekastros, L. Díez Sánchez, F. della Negra, P. Pałka, M. J. Schmidt-Kessen, M. Turpeinen and H. de Verdelhan

\section{Italy}

Federico Della Negra (PhD Researcher, European University Institute)

\section{Statistics}

\begin{tabular}{|c|c|}
\hline Court Level & Number of cases \\
\hline Last instance (civil) & 41 \\
\hline Last instance (administrative) & 1 \\
\hline Civil Court of Appeal & 1 \\
\hline First instance civil court & 4 \\
\hline Total & 47 \\
\hline Type of claimant & Number of cases \\
\hline Individual & 41 \\
\hline Business & 1 \\
\hline $\begin{array}{l}\text { Collective (groups of } \\
\text { individuals) }\end{array}$ & 5 \\
\hline Total & 47 \\
\hline Outcome & Number of cases \\
\hline Claim successful & 37 \\
\hline Claim dismissed & 10 \\
\hline Total & 47 \\
\hline Reasons for dismissal of claim & Number of cases \\
\hline Procedural & 4 \\
\hline No breach of EU law & 0 \\
\hline No sufficient serious breach & 1 \\
\hline No conferral of individual right & 0 \\
\hline No causal link & 0 \\
\hline $\begin{array}{l}\text { No right to damages against } \\
\text { the state (even though the } \\
\text { state breached EU law, the } \\
\text { individual cannot invoke } \\
\text { a subjective right) against } \\
\text { the state) }\end{array}$ & 5 \\
\hline Total & 10 \\
\hline
\end{tabular}




\section{Methodology}

First, to search for the case-law I used several Italian legal databases, such as "Pluris", "Leggi d'Italia" and "Dejure" by looking for the following search words: "Francovich", "Brasserie", "Kobler", "sufficiently serious breach" and "conferral of right". The database "Dejure" has proven to be the most reliable one insofar as it includes the majority of the judgments delivered in the relevant period (2000-2013). As regards the search words, "Francovich" was the most quoted one by Italian Courts which mention it (case reference and name) as a precedent even in the most recent judgments concerning State liability. The search term "Köbler" was useful to find the only relevant case concerning State liability for the breach of EU law related to the exercise of the judicial function. The other search terms give rise to results which were not specifically related to the Francovich liability.

Second, even though the search period has been fixed from 2000 to 2013 I have included also some judgments delivered in 1995 and 1998 to illustrate the context. I think that these cases are of crucial importance to understand the development of State liability in Italy: they show the initial resistance of the Italian Supreme Court in recognizing the Francovich doctrine against the backdrop of the traditional State immunity principle. Moreover, in the report I have included not only the judgments which are directly related to the State liability regime set out in Francovich (e.g. conditions for liability) but also those which are indirectly related to Francovich, such as cases concerning limitation periods. Even though the latter do not really discuss (but rather presuppose) the liability regime set out by Francovich, they are of a certain relevance as they may affect the level of protection granted by the national legal system to the individual.

Third, the most important problem I encountered in this research is certainly related to the scarcity of lower courts judgments available in the databases. Indeed, the Italian legal databases (which are not public) collect and report very few judgments of the first instance (Tribunal) and second instance (Court of Appeal) Courts. For this reason, the report is mostly based on the case-law of the Italian Supreme Court (civil chamber). Moreover, it is not always possible to "reconstruct" the history of the case, on the basis of the judgment of the Supreme Court, insofar as the decisions of the lower Courts are not always mentioned in the final judgments.

\section{Context}

In the leading Francovich judgment the Court of Justice (ECJ) held that Member States are liable for the losses caused to individuals for the breaches of EU law. ${ }^{47}$ This ruling pierced the veil of the State immunity principle which is still affirmed by Italian courts in relation to "domestic" State (legislator) liability. Although legal doctrine has acknowledged that the state can be held liable for damages caused due to the incorrect exercise of the legislative function (e.g. adoption of unconstitutional laws) ${ }^{48}$ Italian courts still refuse to acknowledge this principle. The idea that the legislator cannot be held liable since its action is justified by political and democratic reasons still prevents individuals from being compensated for breaches of national law. During the nineties the same argument was put forward by the Supreme Court in relation to State liability for a breach of EU law.

More recently, Italian Court have abandoned such resistance by designing a liability regime - for breaches of EU law - which is in line with the Francovich judgment. Aside from the breach of EU law, "domestic" State liability is possible only for losses caused by administrative authorities or civil judges. In both cases, however, the liability regime, based on tort law, is narrower than that introduced by Francovich either because the claimant must provide evidence of an intentional or negligent act or

\footnotetext{
${ }^{47}$ ECJ, 19.11.1991, Joined Cases C-6/90 and C-9/90, Francovich.

48 See, in particular, C. Pasquinelli, La responsabilità dello Stato legislatore tra "illecito comunitario" $e$ "illecito costituzionale”. Prime riflessioni, in Riv. dir. civ., 2009, 171 ss.
} 
omission of the public body ${ }^{49}$ or because an intentional fault or serious misconduct in the exercise of the judicial functions must be proven. ${ }^{50}$

\section{Narrative}

Litigation concerning State liability for breaches of EU law essentially focusses on the failure to transpose EU directives by the Italian legislator. In two cases State liability caused by the administrative authorities and civil judges was at stake. The overwhelming majority of cases deal with the incorrect transposition of Directive 1980/987/EEC concerning the minimum level of protection for employees in the event of an employer's insolvency, which gave rise to the Francovich judgment, and Directive 1982/76/EEC, supplementing the Directive 75/363/EEC, concerning the coordination of provisions laid down by law, regulation or administrative action in respect of activities of specialised doctors (44 out of 47 cases). A few cases deal with the incorrect transposition of Directive 1985/577/EEC on doorstep sales and Directive 1995/59/EC on taxes other than turnover taxes which affect the consumption of manufactured tobacco.

In the majority of cases the Italian courts, in particular, the Supreme Court (41 out of 47 cases are decided by the Supreme Court) ruled in favour of the claimant (37 out 47 cases). The other claims were dismissed because the Court affirmed the principle of State immunity (5), for procedural reasons (4) or because the breach of EU law was not sufficiently serious (1). Finally, the judgments examined were generally brought by individuals (41 out of 47 cases). Only in a few cases the claimants were a group (5) or a business (1).

\section{Analysis}

From 1995 to 2013 Italian courts have gradually strengthened the State liability regime for breaches of EU law.

On the basis of their procedural autonomy, Italian courts have divided State liability into three different legal regimes: State immunity, tortious liability and contractual liability for breaches of statutory law. The background of this judicial evolution is mostly provided by the cases related to the failure to transpose Directive 1980/987/EEC (the Francovich follow-up cases) and Directive 1982/76/EEC. However, in the first Francovich follow-up cases the Supreme Court followed a conservative approach and held that an individual cannot invoke any subjective right to the correct exercise of legislative power by the Parliament. ${ }^{51}$ For this reason, the failure to transpose the Directive could not give rise to an unlawful omission in the national legal order.

In 1998, the Supreme Court stated, for the first time, that such omission was to be regarded as an "unlawful omission" in the meaning of Art. 2043 c.c. ${ }^{52}$ By acknowledging the principle of primacy of EU law, the Court admitted that a breach of EU law automatically resulted in a breach of national law. ${ }^{53}$ However, in many cases (mostly related to the dispute concerning the implementation of

\footnotetext{
${ }^{49}$ This principle was firstly recognized by the Supreme Court (Plenary session), 22.7.1999, n. 500.

${ }^{50}$ Art. 2 of law n. 117/1988.

${ }^{51}$ See Cass., 11.10.1995, n. 10617; Cass., 9.1.1997, n. 133; Cass., 7.7.1998, n. 6613; Cass., 10.2.1998, n. 1366; Cass., 1.4.2003, n. 4915

${ }^{52}$ Cass., 11.6.1998, n. 5846.

${ }^{53}$ See Tribunal of Bari, 30.11.2007, n. 76; Tribunal of Catanzaro, 20.4.2009 and See Cass., 12.2.2008, n. 3283; Cass., 11.3.2008, n. 6427.
} 
Directive 1982/76/EEC) in which State liability was established in principle, no compensation was awarded to the claimants because of the expiry of the five-year limitation period. ${ }^{54}$

This problem was partially overcome by a landmark decision delivered by the Supreme Court (Plenary Session) in 2009. ${ }^{55}$ In this ruling the Supreme Court applied the contractual liability regime to State liability claims. This is contractual liability sui generis as it does not apply to a breach of contract but rather to the breach of statutory law. ${ }^{56}$ From a practical point of view, this regime seems much more consistent with the Francovich ruling than the tortious one as the claimant is not required to prove the negligent or intentional conduct of the state. In spite of that, the "theoretical foundations" supporting this revirement do not seem entirely convincing from the EU law perspective. Indeed, the Court recalled and reused the argument already put forward more than ten years before to dismiss State liability claims: state immunity. As the legislative action is always justified by political reasons, it follows that tort law, which presupposes the existence of an unlawful damage (non jure and contra jus) caused by an act or omission, contradicts, in its essence, the immunity principle. For this reason, only a liability system that does not entail such unlawful damage is compatible with State liability. Thus, the Supreme Court bridged the "past" and the "future": the State immunity principle, founded on the constitutional theory of the two different and separated legal orders, ${ }^{57}$ has become the reason to justify the shift from the tortious to the contractual liability regime.

Two years later the Supreme Court reviewed this argument and interpreted both private and constitutional law in line of the "Francovich doctrine". 58 In this case, concerning the transposition of Directives 1975/362/EEC and 1982/76/EEC, the Court confirmed that State liability must be treated in contract for the breach of the statutory obligation deriving from the Treaties. More notably, it pointed out that the fact that the claim is in contract (and not in tort) does not mean that the state's omission is not unlawful in the Italian legal order. In addition to this, the Supreme Court had the occasion to discuss another crucial issue which had arisen after judgment n. 9147/2009. In the latter decision the Court did not provide any guidance as regards the date on which the limitation period starts to run (dies a quo). The relevant question was whether this period starts at the time when the state has correctly transposed the Directive, as the Court of Justice held in the Emmott case, ${ }^{59}$ or even before, namely the date on which the damage occurred, as the Court of Justice held in the Slagterier case. ${ }^{60}$ The Supreme Court, ruling against its own precedent according to which the limitation period begins to run from the time that the damage occurred even if it is before the implementation of the Directive ${ }^{61}$ held that this period cannot begin before the time the Directive is implemented in the national legal system. In fact, only from that time the individual is supposed to have effective knowledge of the Directive and will the time start to run for the purpose of statutory limitation periods.

To conclude, in spite of the initial resistance to the Francovich judgment, Italian courts have finally developed a liability regime which is consistent with EU law. Accordingly, the individual must only prove the damage and the causal link between the failure to transpose a directive and the damage.

\footnotetext{
54 See Cass., 2001, n. 5249; Cass., 2001, n. 15332; Cass., 3.6.2009, n. 12814. See, also for lower courts decisions: Trib. Roma,14.6.2004 and Trib. Catania, 28.2.2004.

${ }^{55}$ See Cass., sez. un., 17.4.2009, n. 9147.

${ }^{56}$ It must be recalled that according to the article 1173 civil code (c.c.), a legal obligation may arise not only from the contract or an unlawful act or omission but also from statutory law. The breach of such obligation, whatever its legal source is, gives rise to a claim in contract law under article 1218 c.c.

${ }^{57}$ Corte cost., 14.3.1964, n. 14. This line of argument was overcome by the decision of the Constitutional Court of the 8.6.1984, n. 170 .

${ }^{58}$ Cass., 17.5.2011, n. 10813.

${ }^{59}$ ECJ, 25.7.1991, C-208/90, Emmot.

${ }^{60}$ ECJ, ECJ, 24.3.2009, C-445/06, Slagterier.

${ }^{61}$ Cass., sez. I, 10.3.2010, n. 5842.
} 
Moreover, insofar as the claim is in contract, the ten-year limitation period starts from the date on which a directive has been correctly transposed. Nevertheless, the limitation period still constitutes a decisive factor which limits the effects of the Francovich judgment. A clear demonstration of this is provided by the recent law 12.11.2011 n. 183 which establishes that the limitation period for State liability claims must be fixed at 5 years (Art. 4 (43) of the law). ${ }^{62}$ This provision, according to the Supreme Court, shall apply only to damages which occurred after the entry into force of the legislation.

${ }^{62}$ See Cass. 9.2.2012, n. 1850; Cass. 22.3.2012, n. 4538. 


\section{The Netherlands}

Barend van Leeuwen ( $\mathrm{PhD}$ Researcher, European University Institute)

\section{Statistics}

\begin{tabular}{|c|c|}
\hline Area of law & Number of cases \\
\hline Agriculture & 4 \\
\hline Asylum and immigration & 1 \\
\hline Employment & 4 \\
\hline Environmental protection & 1 \\
\hline Free movement of goods & 2 \\
\hline Social security & 1 \\
\hline State aid & 1 \\
\hline Taxation/Customs & 6 \\
\hline Total & 21 \\
\hline Court level & Number of cases \\
\hline Last instance & 7 \\
\hline Court of Appeal & 8 \\
\hline First instance & 6 \\
\hline Total & 21 \\
\hline Type of claimant & Number of cases \\
\hline Individual & 9 \\
\hline Business & 9 \\
\hline $\begin{array}{l}\text { Collective (group of individuals, } \\
\text { group of businesses, } \\
\text { associations) }\end{array}$ & 3 \\
\hline Total & 21 \\
\hline Outcome & Number of cases \\
\hline Claim successful & 4 \\
\hline Claim dismissed & 17 \\
\hline Total & 21 \\
\hline
\end{tabular}




\begin{tabular}{|c|c|}
\hline Reason for dismissal of claim & Number of cases \\
\hline $\begin{array}{l}\text { Procedural (incl. limitation } \\
\text { period) }\end{array}$ & 5 \\
\hline No breach of EU law & 7 \\
\hline No sufficiently serious breach & 3 \\
\hline No conferral of individual right & 1 \\
\hline No causal link & 1 \\
\hline Total & 17 \\
\hline
\end{tabular}

\section{Methodology}

The database which I used was www.rechtspraak.nl, which is a public database which is freely accessible. It is managed by the Dutch Court Service. The database includes reported cases from 2000 onwards. Not all cases in the Netherlands are reported. The cases which are published on www.rechtspraak.nl are already a selection.

I searched for Francovich cases up to 31 December 2013. The aim was to search for relevant cases in which Francovich liability was discussed as a real possibility. The following search terms were used:

1. Francovich

2. Factortame

3. Brasserie du Pecheur

4. Köbler

5. Sufficiently serious breach ("voldoende gekwalificeerde schending")

6. Breach of Community Law ("schending van het gemeenschapsrecht")

The criterion of sufficiently serious breach was particularly helpful to identify cases in which Francovich liability was considered as a real possibility. A total of 21 relevant cases were identified. In 17 of them the claim for Francovich liability was dismissed, while in 4 the claim was successful.

\section{Context}

Dutch law does not have a statutory or constitutional provision about the conditions under which the State is liable to pay damages for harm caused by it. As a result, State liability has been developed by analogy with the legislative provision on civil liability for an unlawful act (Article 6:162 BW). Five conditions can be identified. First of all, there must have been an unlawful act by the State. The adoption of legislation can be unlawful. Secondly, this unlawful act must be attributable to the State. Thirdly, the rule or norm which has allegedly been breached must have been intended to provide protection to the party which is bringing the claim ("relativiteitsbeginsel"). Fourthly, there must have been a causal connection between the breach and the damage which has been suffered. Finally, the claimant must have suffered damage.

It is clear that the conditions for State liability under Dutch law are relatively similar to those under EU law. However, the most important difference is that there is no requirement of a sufficiently serious breach. Dutch law only requires an unlawful act. Therefore, it would seem that the requirements under Dutch law are more favourable than under EU law. On that basis, one would assume that State liability claims would normally be brought under national law and that there 
would be few Francovich cases. The relationship between national State liability law and State liability under EU law has recently been discussed by the Court of Appeal of The Hague and will be analysed below.

\section{Narrative}

In total, twenty-one relevant cases were found. Most of the cases were brought in the field of taxation. In these cases, Francovich State liability was usually not the main claim. Another area of law in which there were a significant amount of cases was agriculture. Francovich State liability was claimed in all levels of court - seven cases were last instance cases (not only the Supreme Court, but also the specialised College van Beroep voor het Bedrijfsleven tribunal, which is the court of last instance for a number of areas within the scope of EU law), eight claims were in the Court of Appeal and six cases were first instance cases in the High Court. Relatively few cases were collective actions, while the number of cases brought by individuals and business was similar (nine).

Four of the cases were successful, although it should be noted that on appeal in two of the cases the Court of Appeal held that because the state was liable under national law criteria, there was no need to discuss the Francovich criteria. All successful cases were brought in the same High Court and were about the same issue. This could indicate that lower courts are more willing to award damages on the basis of the Francovich criteria, but there is insufficient evidence for this claim to be convincing. Of the seventeen cases in which the Francovich claim was unsuccessful, in seven cases this was because the court found that there had not been a breach of EU law. Five cases were dismissed because of procedural reasons. This could be because the claims had been brought after the limitation period had expired, or because they were brought in the wrong kind of court. Because State liability was developed out of civil liability, administrative courts or tribunals do not have jurisdiction to award Francovich damages, for which separate proceedings have to be brought in the civil courts. In seven cases - including the four successful cases - the courts engaged in a discussion of whether a breach of EU law was sufficiently serious.

\section{Analysis}

The relationship between State liability under national law and State liability under EU law

The four successful cases were all first instance judgments decided by the High Court of The Hague three of them by the same judge. The judgments follow the same structure and are more or less identical. They are about the right to paid annual leave of employees who were on sick leave. The right to paid annual leave is laid down in Article 7 of Directive 2003/88/EC. The question was whether employees who were on sick leave were also entitled to paid annual leave. Dutch legislation provided that this was not the case. However, after the judgment of the ECJ in Schultz-Hoff in 2009 the legislation was amended. The claimants argued that the Dutch legislation should already have been amended after the judgment of the CJEU in Bectu in 2001. They submitted that the failure of the Dutch State to amend the legislation in a reasonable time period after the judgment should result in State liability. The discussion of the conditions of liability will be analysed below. The High Court went through all three Francovich criteria and decided that the Dutch State was liable. The State appealed and all cases came before the Court of Appeal of The Hague. There was also a cross-appeal by the claimants who argued that the conditions of liability under national law should have been applied. The Francovich conditions were only minimum criteria and it ought to be possible for national law to apply criteria which were more favourable to claimants. Dutch national law was more favourable. The simple adoption of legislation which was incompatible with EU law constituted an unlawful act which entitled the claimants to claim damages. The State argued that the adoption of legislation could not give rise to a claim of damages since it did not constitute an unlawful act. 
Although the incompatibility of the legislation could give rise to the non-application of the incompatible legislation, as a matter of Dutch law it did not follow that there should be a private law remedy for the claimants. Two of the appeals were decided in 2013, while two other cases were decided in 2014 and could not be included.

The Court of Appeal dismissed the appeal but allowed the cross-appeal of the claimants. It held that the criteria under Dutch law were more favourable and that there was no need to assess the case on the basis of the Francovich criteria. This is the first such decision of a Dutch court and it would mean that the Francovich criteria have become more or less redundant. Nevertheless, there could still be areas in which the Francovich criteria could be applied, such as in cases of an erroneous interpretation of EU law by national courts (Köbler). Moreover, there could be other areas in which Francovich liability still has something to add to national law. However, in general, it would seem that national law provides a more favourable route to claimants. The judgments of the Court of Appeal could result in more State liability claims for breaches of EU law.

\section{The interpretation of the criterion of "sufficiently serious breach" by Dutch courts}

There were a number of cases in which the courts discussed in what circumstances a breach of EU law could be considered to be sufficiently serious for the purposes of State liability. The series of cases already described above provide a good example. The starting point of the court in those cases was that this was not a case of non-implementation, but one of an erroneous interpretation and implementation of the Directive. In such cases, the state would be liable if it had gravely and manifestly disregarded the limits of its discretion. The answer to that question depended on the clarity of the relevant provision of EU law. In Bectu, a judgment delivered in 2001, the CJEU had already explained how Article 7 of Directive 2003/88 had to be interpreted. After this judgment, it was no longer possible for the Dutch State to interpret Article 7 in the way that it did. Although the State was given a reasonable period to amend the legislation to comply with the requirements of EU law, this period had been well exceeded. As a result, the breach of EU law was sufficiently serious and was based on the omission of the Dutch State to amend the legislation after the CJEU's judgment.

In another case, the claimant was a Ukrainian national who wanted to bring her husband to the Netherlands under the Family Reunification Directive. Leave to remain in the Netherlands was refused by the Ministry. After the judgment of the CJEU in Chakroun in 2010, the relevant Dutch legislation was amended. The claimant brought an action for State liability and argued that by dismissing the application the Ministry had intentionally acted in breach of EU law. The High Court of the Hague held that the breach of EU law had not been sufficiently serious. It was not until the judgment of the CJEU in Chakroun that the correct interpretation of the Family Reunification Directive had become clear. The fact that the Raad van State (the highest court for certain administrative law matters) had already expressed doubts about the compatibility of the Dutch legislation with EU law in 2004 was not sufficient for the breach to be sufficiently serious - on the contrary, it confirmed that there were doubts about the correct interpretation.

Finally, in a case decided by the Court of Appeal of Arnhem, the claimant was a Dutch citizen who lived in England and had appealed the imposition of a tax levy by the Ministry. The claimant claimed that a particular levy, including a requirement of a surety, breached Article 43 EC. The case was referred to the CJEU which held that the Dutch taxation system, which provided for a particular levy in the claimant's situation, breached Article 43 EC. When the case returned to the Court of Appeal, it held that the breach was not sufficiently serious. The Court of Appeal held that

"it cannot be said that the Netherlands has manifestly and gravely breached that obligation by incorporating in the legislation in question a compulsory surety to be able to get an extension to pay the imposed tax. The fact that certain Members of Parliament expressed doubts about the compatibility of the legislation in question with EC law when the legislation was adopted does not result in a different 
conclusion. The Court further notes that the Dutch system has not been found to be obstructive in its entirely by the ECJ, but only in so far as it imposed the requirement of a compulsory surety to get an extension of payment of the imposed tax, and in so far as it did not take into account possible deductions in value which might have taken place after the departure at the moment of actual alienation".

It also added that the wording of Article $43 \mathrm{EC}$ was not clear and that there was a significant amount of disagreement in the academic literature. 


\section{Poland}

Przemysław Pałka (PhD Researcher, European University Institute)

\section{Statistics}

Two relevant cases were found, based on the same legal and similar factual background

1. Area of law: 2 Financial services (MIFID I\&II)

2. Court level: 1 Court of Appeals, 1 Supreme Court

3. Type of claimant: 2 Business

4. Outcome: 2 Unsuccessful

5. Reason for dismissal of claim: 2 Lack of causation

\section{Methodology}

I conducted a thorough research of three databases, two public and one commercial. Since only two cases were found, I have re-done it, with a significantly higher number of search terms. Francovich liability, in a more flexible form (not-requiring the breach to be serious), has been internalized into the Polish Civil Code, as a part of State (State Treasury's) liability. It is, therefore, possible that Francovich cases have been adjudicated without mentioning any CJEU case-law. That is why I also use terms specific for this type of liability in the national system. In this short section, databases and the justification for their choice are indicated, and list of all the search terms used in each of them listed (together with results) in the tables below.

Databases searched

Public databases

a) Portal Orzeczeń Sądów Powszechnych (Portal of the Common Courts' Judgments)

Available at: http://orzeczenia.ms.gov.pl/ (Polish only)

Public database, run by the Ministry of Justice (pol. Ministerstwo Sprawiedliwości), containing judgments of the district courts (pol. sad rejonowy), the regional courts (pol. sad okregowy) and the appellate courts (pol. sad apelacyjny).

Justification of choice of the database: Common courts in Poland (pol. sqdy powszechne) adjudicate in all the types of cases, apart from administrative cases and military cases. Any case regarding liability, particularly State liability, would be adjudicated by a common court. This database contains all the published judgments of the common courts in Poland.

b) Baza Orzeczeń Sądu Najwyższego (Database of the Supreme Court's Judgements)

Available at: www.sn.pl/orzecznictwo (Search option and judgments available in Polish only).

Public database, run by the Supreme Court (pol. Sąd Najwyższy), containing all the published judgments of the Supreme Court.

Justification of choice of the database: Supreme Court in Poland adjudicates as the court of cassation, when the judgment of the court of second instance is claimed unlawful in terms of substance or procedure. Together with the previous database, if any Francovich judgment has been published, it would have to be either in one or another. 
Private databases

a) LexPolonica

Available at: http://lponline.lexpolonica.pl (Polish only)

Commercial database, run by LexisNexis, containing Polish legislation and judgments of Polish courts. One of the three biggest and most popular (next to Legalis by C.H. Beck and Lex by Wolters Kluwer) commercial legal databases in Poland, the only one available at the EUI.

Justification of the choice of the database: It is legally and technically impossible for this database to contain any judgment not present in the previous two. However, I decided to use it, since the key-words and tags used in it might vary, therefore there was a chance I could find judgment that I would have missed in the previous ones.

Public databases search both in the text itself and by key-words. Since it is possible that a Francovich case is adjudicated without mentioning any CJEU case, just on national law grounds, in the public databases I also used phrases characteristic for this type of liability. Below, I indicate how many judgments labelled with particular tags were found ('found judgments') and then perform content analysis to indicate how many of them have actually been about Francovich-like liability ('Francovich judgments'). There were only two and they often appeared in different searches.

\section{Context}

Historically, State liability is a young phenomenon in Polish private law, institutionalised only during the process of democratisation and Europeanisation after 1989. In the previous version of the Civil Code, civil liability of the state, especially of the legislature, was non-existent and as a concept almost unanimously contested in the doctrine. This has changed directly under the inspiration of the CJEU case law ${ }^{63}$.

Civil liability of the State was confirmed and codified in art. 417 of the Polish Civil Code (introducing civil liability of the State Treasury for losses caused by public authorities) and art. $417^{1}$, introducing specific regimes of liability, which states as follows (translation is mine, P.P.):

Art. $417^{1}$

$\S 1$. If the loss has been caused by a legal act, remedies can be claimed after this act had been proven contrary to the Constitution, a ratified international agreement or an act of the Parliament, in the proper proceedings.

$\S 2$. If the loss has been caused by a final judgment or a final administrative decision, remedies can be claimed after this judgment or decision had been declared unlawful in the proper proceedings, unless specific provisions state otherwise. This applies as well to situations when the final judgment or the final decision has been based on an act contrary to the Constitution, a ratified international agreement or an act of the Parliament.

$\S 3$. If the loss has been caused by not issuing a judgment or a decision, when there exists a legal obligation to issue them, remedies can be claimed after unlawfulness of the lack of issuance had been proven in proper proceedings, unless specific provision state otherwise.

$\S 4$. If the loss has been caused by not issuing a legal act, when there exists a legal obligation of its issuance, unlawfulness of this non-enactment is stated by the court recognizing the case for damages.

${ }^{63}$ Banaszczyk, Zbigniew; Szczególne, przewidziane w Kodeksie cywilnym, przypadki odpowiedzialności za szkody wyrzadzane niezgodnym z prawem działaniem lub zaniechaniem przy wykonywaniu władzy publicznej (art. $417^{1} K C$ ), [in:] Olejniczak, Adam, SYSTEM PRAWA PRYWATNEGO. TOM 6 - PRAWO ZOBOWIĄZAŃ, CZĘŚĆ OGÓLNA; C.H. Beck, Warszawa 2014 [[System of Polish Private Law]]. 
This article, read together with the general delict clause in art. 415 (Whoever has culpably caused another person a loss, is obliged to repair it), provides for State liability for damages caused by the legislature, administration and judicature - both for unlawful acts and failures to act. This also comprises Francovich liability, and does so in a more flexible way, since no 'serious breech' is needed. This loosens the requirements for Francovich liability, but at the same time 'internalises' this type of liability fully into national law ${ }^{64}$.

\section{Narrative}

I managed to find two Francovich cases - both related to Poland's delay in transposition of the MIFID directives; both claimed by business actors; both unsuccessful because of the lack of causation. One was decided by the Court of Appeals, one by the Supreme Court. In both cases State liability was considered a serious option.

\section{Analysis}

As noted above, both cases were concerned with the same legal question. In both cases, the courts seemed ready to grant Francovich liability (since it was internalised into the Polish Civil Code), but in both cases they found a lack of causation between the State's delay in transposing the MIFID Directives and the losses suffered. In one case, the company had already been engaging in very risky operations regardless of any information about the risk for a long time; in the other one the transaction concluded with the bank would be and was lawful under the MIFID regime).

Two cases is not many for 10 years. However, a number of observations can be made.

Polish courts, especially the Supreme Court, often analyse CJEU judgments, in particular Köbler, while adjudicating in purely national cases, even when they do not involve EU law. This might be due to the fact that the very idea of State liability was introduced together with the obligation to internalise Francovich liability.

There was quite a significant amount of cases where private parties tried to invoke the horizontal direct effect of directives, e.g. by suing an employer or a bank, instead of the state. It might take time for our practitioners to understand the whole EU law regime. One of the two cases I managed to find does not refer to any CJEU judgment - it is based entirely on national law. That is why I decided to use so many different search terms.

\footnotetext{
${ }^{64}$ Bieniek, Gerard, Czyny niedozwolone (art. 415-449 KC); [w:] Bieniek, Gerard; Ciepla, Helena (...) Komentarz do Kodeksu cywilnego. Księga trzecia. Zobowiazania tom I, LexisNexis, Warszawa 2011 [[Commentary to Polish Civil Code]]
} 


\section{Spain}

Leticia Díez Sánchez (PhD Researcher, European University Institute)

\section{Statistics}

\begin{tabular}{|c|c|}
\hline Area of law & Number of cases \\
\hline \multicolumn{2}{|l|}{ Agriculture } \\
\hline \multicolumn{2}{|l|}{ Asylum and immigration } \\
\hline Employment & 4 \\
\hline \multicolumn{2}{|l|}{ Environmental protection } \\
\hline Free movement of goods & 4 \\
\hline Social security & 4 \\
\hline \multicolumn{2}{|l|}{ State aid } \\
\hline Taxation & 129 \\
\hline Consumer protection & 2 \\
\hline Total & 143 \\
\hline Court level & Number of cases \\
\hline Last instance & 133 \\
\hline Court of Appeal & 10 \\
\hline \multicolumn{2}{|l|}{ First instance } \\
\hline Total & 143 \\
\hline
\end{tabular}

Most of cases in the taxation field relate to VAT; only 3 of them were litigation in other fields within the taxation category.

\begin{tabular}{|c|c|}
\hline Type of claimant & Number of cases \\
\hline Individual & 11 \\
\hline Business & 116 \\
\hline Collective & 16 \\
\hline Total & 143 \\
\hline Outcome & Number of cases \\
\hline Claim successful & 130 \\
\hline Claim dismissed & 13 \\
\hline Total & 143 \\
\hline
\end{tabular}




\begin{tabular}{|l|c|}
\hline \multicolumn{1}{|c|}{ Reason for dismissal of claim } & \multicolumn{1}{c|}{ Number of cases } \\
\hline $\begin{array}{l}\text { Procedural (incl. limitation } \\
\text { period) }\end{array}$ & $\begin{array}{l}\sim \text { 1 (see Case 127 regarding } \\
\text { some of the claimants) }\end{array}$ \\
\hline No breach of EU law & 1 \\
\hline No sufficiently serious breach & 5 \\
\hline No conferral of individual right & 3 \\
\hline No causal link & 3 \\
\hline Total & $\mathbf{1 2 + \sim 1}$ \\
\hline
\end{tabular}

The term "Collective" included associations, foundations and a city council. Public businesses are marked as "Business*" and explained afterwards. In some of the VAT cases the claimant is an individual - but a link to a commercial activity is supposed in the context.

\section{Methodology}

I used the Spanish database "Aranzadi" to search for case-law. 'Aranzadi' gathers all the cases from lower and higher judicial instances shortly after they have been delivered. I examined all judgments available during the period $1^{\text {st }}$ January 2000 to $31^{\text {st }}$ December 2013.

I inserted "Francovich" in the field "Text" - which produced all the judicial decisions, in lower and higher courts, where Francovich had been mentioned either by the parties or by the Court. This gave 864 results. In order to reduce the search results to those relevant for the project, the legal term "Pecuniary responsibility of the Public Administration" was selected from the list of legal terms in the field "Voices" (Voces).

In order to ensure that no relevant cases were missed, this search was repeated substituting "Köbler" for "Francovich". This did not give any further results. The search was again repeated substituting "Factortame" for "Francovich". On this occasion, one more relevant case was found and added to the case sheets.

In total, 153 cases were found using these search techniques. A close reading showed that only 143 of them were relevant according to the methodology above. By way of final note, introducing a legal term ("Pecuniary Responsibility of the Public Administration") within the search results presents the risk of missing cases that had not been codified by Aranzadi under such legal term. In other words, it renders the search results dependant on a previous consistent codification by the database. While the possibility of mistake is very little, this could be taken into account in further research.

\section{Context}

The regime for State liability in Spain was traditionally based on strict liability. The conditions for this were (1) the existence of an economically quantifiable damage, (2) the authorship of the public administration (this was interpreted in a broad sense) and (3) a direct causal link between the actions of the administration and the damage.

The model of liability developed by Francovich is not radically different, but Spanish legislation does not require the legislation in question to give rights to an individual or the damage to be sufficiently serious. It only requires that the individual in question has suffered a damage that she did not have the obligation to bear. What Francovich has added to the Spanish legal system is the obligation to assimilate damages suffered by unconstitutional actions to those suffered by non-implementation or 
wrong implementation of directives (no need to exhaust previous administrative actions, the possibility to request damages directly through judicial procedures). Previously, breaches of EU law could be brought to courts within the same formal requirements as those caused by breaches of ordinary Spanish legislation (initial request of damages through administrative procedures within the time-limits established by the relevant legislation on the matter).

\section{Narrative}

143 relevant cases were found, out of which 130 were successful. A disproportionate number of cases (129) belong to the field of taxation. The 126 tax cases originated in a breach of the Sixth Directive (on a common system of VAT tax) that triggered litigation which came to an end after the CJEU held that Spain had breached the Directive. Although the factual background to most of these cases is nearly identical, claims for pecuniary responsibility were made individually - hence the large number of cases with similar judicial reasoning.

In addition to the "VAT saga", three other cases in the field of tax law were also successful, two of them on the basis of Directive 69/335/EC concerning indirect taxes on the raising of capital and another one on the basis of income tax for non-residents. In additional, four cases were brought in the field of free movement, of which one was successful. Four cases were brought in the field of employment: two unsuccessful, regarding the Working Time Directive; and two regarding redundancy payments (one of which was successfully litigated). Four unsuccessful claims were raised in the field of social security (pensions). Finally, one case related to consumer protection was successful and another one unsuccessful.

In terms of the type of claimants, the great majority (116) of the cases were initiated by businesses. Although 11 cases were initiated by individuals, the real number of actions brought by individuals could be smaller as within the VAT saga a link with commercial activity is to be supposed. The remaining 16 cases were brought by collective actors (this includes associations, foundations and a city council). It is interesting that with regard to the VAT saga, some of the claimants were public or semi-public bodies. This is the case because Spain is a decentralised polity (towards regions and municipalities), yet VAT is paid to the central government. Hence, some of the cases illustrate an interesting conflict not between the public and the private sphere, but between different levels of government.

133 of the judgments found were by a court of last instance. However, most of the cases at last instance did not stem from a prior appeal but from an appeal of administrative acts - pecuniary responsibility from the Administration was requested through a special administrative procedure. Should the administrative resolution be appealed, these appeals go directly to a higher court. The remaining 10 cases were before a Court of Appeal.

The absence of a sufficiently serious breach was the main reason for dismissal (it was claimed in 5 cases), most remarkably in cases of flagrant violation of the Working Time Directive. Lack of conferral of a right was alleged by the Spanish Courts in 3 cases, and the lack of causality was put forward in other 3 cases. In one of the successful cases (Alain F, \#127) some of the claimants were not awarded compensation for procedural reasons (having exceeded the time period for lodging a legal action after the damage had been caused). Lastly, in Forum Filatélico (\#143) the Court considered that the case was outside the scope of the relevant EU legislation on the matter.

\section{Analysis}

The overall picture of Spain is one of compliance with the Francovich criteria for the award of damages: 130 out of 143 actions were successful. However, these data need some qualification. 


\section{Previous CJEU judgments}

While previous judgments of the CJEU that found Spain in breach of EU law are not needed per Alain $F$. (Case \#127 in the casesheets) or per Eusebio Ramón (Case \#130), such decisions were relevant in the VAT saga (cases \#1 to \#126), in Dekan (Case \#139), in Canal Satélite Digital (\#141) and in SAGE (\#142). As to the VAT saga, the CJEU first declared that Spanish legislation was against the Sixth Council Directive (C-204/03) and, later, required that Spanish authorities allow requests for damages under EU law to be dealt with in the same manner as those emanating from unconstitutional acts (C118/08). In Dekan, SAGE and Canal Satélite Digital, a previous decision of the CJEU that held Spain had acted contrary to EU law, was of crucial importance in order to establish a sufficiently serious breach.

It is noted in this regard that the lack of a condemnatory judgment by the CJEU was presented by the Supreme Court as evidence against the existence of a sufficiently serious breach in Biostab (Case \#136). Closely related to this claim is that of denying a sufficiently serious breach on the basis that the Commission had not started judicial proceedings against Spain (Case D. Eulogio, \#138). In addition, the fact that the CJEU did not include Laboratorios Tegor within a list of companies affected by a Spanish breach of EU law lead the Supreme Court to reject this company's claim for damages (Case \#137).

\section{Sufficiently serious breach}

EU law does not lead to damages in cases related to the Working Time Directive, for the breach is not considered by the Spanish Courts to be sufficiently serious (Cases \#129 Doña Olga, \#128 Cuerpos Facultativos) because of the ambiguous interpretation that could be given to the Directive. It seems paradoxical that if the same case had been decided exclusively under domestic law, damages would have most likely been awarded as the claimant would not have needed to prove the seriousness of the damage. Similarly, the court would not have had to assess the margin of appreciation of the administration.

\section{The strategic use of Francovich}

As has been mentioned, the VAT saga provides evidence that not only companies pursue a remedy against the actions of the public administration, but that public administrations of other territorial entities within Spain also bring Francovich actions. This opens up an interesting route for further research: the strategic use of Francovich by different power centres in decentralised polities. 


\section{The United Kingdom}

Rónán Condon and Barend van Leeuwen (PhD Researchers, European University Institute)

\section{Statistics}

\begin{tabular}{|c|c|}
\hline Area of law & Number of cases \\
\hline Agriculture (including fishery) & 3 \\
\hline Asylum and immigration & 3 \\
\hline Employment & 5 \\
\hline Environmental protection & 1 \\
\hline $\begin{array}{l}\text { Free movement of } \\
\text { goods/services }\end{array}$ & 2 \\
\hline $\begin{array}{l}\text { Social security (Including } \\
\text { Insurance) }\end{array}$ & 4 \\
\hline \multicolumn{2}{|l|}{ State aid } \\
\hline Taxation & 3 \\
\hline Free movement of persons & 0 \\
\hline Financial Services & 1 \\
\hline Copyright & 2 \\
\hline Right to Vote & 1 \\
\hline Total & 25 \\
\hline Court level & Number of cases \\
\hline Last instance & 3 \\
\hline Court of Appeal & 7 \\
\hline First instance & 15 \\
\hline Total & 25 \\
\hline Type of claimant & Number of cases \\
\hline Individual & 10 \\
\hline Business & 4 \\
\hline $\begin{array}{l}\text { Collective (group of individuals, } \\
\text { group of businesses, } \\
\text { associations) }\end{array}$ & 11 \\
\hline Total & 25 \\
\hline
\end{tabular}




\begin{tabular}{|c|c|}
\hline Outcome & Number of cases \\
\hline Claim successful & 1 \\
\hline Claim dismissed & 24 \\
\hline Total & 25 \\
\hline Reason for dismissal of claim & Number of cases \\
\hline $\begin{array}{l}\text { Procedural (incl. limitation } \\
\text { period) }\end{array}$ & 3 \\
\hline No breach of EU law & 3 \\
\hline No sufficiently serious breach & 10 \\
\hline No conferral of individual right & 7 \\
\hline No causal link & 0 \\
\hline Preliminary Reference & 1 \\
\hline Total & 24 \\
\hline
\end{tabular}

\section{Methodology}

We used both westlaw.co.uk and bailii.org to search for Francovich liability judgments. The main search terms used were, 'State liability', 'sufficiently serious breach', and 'conferral of a right'. In addition, a number of leading cases were used as search terms, such as 'Francovich', 'Brasserie du Pecheur', 'Köbler', 'Brinkmann', 'Factortame' and so on. From an initial find of over 80 judgments, these were filtered in accordance with our 'relevance' requirement. Other cases were deemed relevant in addition to the discussion of these points e.g. if limitations periods were discussed. This means that there is an average of two cases per year which reach High Court-level at least.

\section{Context}

The common law of England and Wales has traditionally recognised no general principle of State liability. A claimant was required to argue on the basis of breach of statutory duty or the common law duty of care. Policy arguments, and the theory of parliamentary sovereignty tend to militate against recovery. Otherwise, ordinary tort law causes of action are applicable but normally if the claim is pursued against individual public officials, the claim is required to fit within ordinary torts such as defamation, assault and so on. The only distinctively public tort is misfeasance in public office, which requires proof of mala fides on behalf of a public official. It appears that the requirement of mala fides has been relaxed in recent years but this remains a developing area of law. In consequence, the concept of a general claim against the state for its acts or omissions is novel in an English law context.

\section{Refraction: Breach of statutory duty sui generis}

The Factortame-saga has cast a shadow over the jurisprudence of the Superior courts. It is notable that when Factortame 'came home' in Factortame VI. HHJ Toulmin categorised Francovich as a breach of statutory duty sui generis. This rather unhelpful epithet seems to elide two distinct categories of recovery. The former is based on construing the 'intention of Parliament' which rests on the theory of parliamentary sovereignty and is coloured in its development by policy factors, and the latter on the entirely different European basis for recovery; or as Giliker refers to Francovich, the 'Eurotort'. In 
Factortame VI the relevant question was whether Francovich could be treated as akin to national law for the purposes of time limitations in tort.

\section{Narrative}

To date our research has indicated that there have been 25 decisions of the Superior Courts on in which Francovich was a relevant factor. In all but one of these cases the claimant did not succeed in his claim. Most of the claims relate to social security (8), and other important categories of claims include taxation (4), and more recently immigration and asylum (4).

In any case concerning Framework Directives (e.g. Sayers v Cambridgeshire CoCo [2006] EWHC 2029) the Framework Directive was considered too imprecise to give rise to liability.

The Courts are not shy to refer cases to the CJEU, although they have refused references on a number of occasions where perhaps it was required (Alderson, Three Rivers).

\section{Analysis}

\section{Conferral of a right}

It appears that the analogy with breach of statutory duty which flows from the cloudy formulation of the tort in the High Court seems to reappear in Three Rivers and subsequent judgments. In Three Rivers, a case in which the claimants sought to impute a duty to supervise on the Bank of England resulting in liability for failure to do so adequately, the corollary of a right purportedly flowing from the relevant directive, the Court's interpretation of conferral of a right is at the very least restrictive. In that case Lord Hope departed from the CJEU's approach in Dillenkofer and distinguished between the primary purposes and secondary purposes of the Directive. If we recall, in Dillenkofer the CJEU reasoned that if a directive has more than one purpose this is not a sufficient reason to argue that rights were not intended to be conferred. The learned judge held that depositor protection was a secondary purpose of the Directive and therefore no rights were conferred on the claimants. He supported his interpretation of the Directive by reference to the fact that there was no express grant of rights on the face of the Directive and arguably eschewed a purposive approach.

To an extent the House of Lords was vindicated in its approach by Paul. However, this narrow approach which searches for 'express' wording and 'intention' was applied in other areas which do not relate to banking regulation. In Poole this narrow approach was followed in the area of insurance. In Millward $v$ Oxfordshire CoCo the case concerned a claim for personal injuries pursuant to Council Directive 89/391. This Directive was implemented into UK law by the Management of Health and Safety at Work Regulations 1992. The Court obiter followed Lord Hope in Three Rivers in two respects. First, by adopting a test which posed the question of whether the conferral of a right was 'strictly necessary'. Second, by an approach to statutory interpretation that seems more appropriate for determining whether there is a breach of statutory duty. In this regard, the Court considered that the Directive '...is aimed at imposing general obligations on employers, not at conferring rights on individuals.' The Court cited Lord Hope's approach with approval. To determine the aim of the Directive the approach followed was to narrowly focus on the express wording of the Directive at the apparent expense of its purpose.

Therefore, our research to date indicates a tendency to use conferral of a right as a control mechanism. In numerical terms, 7 cases have been dismissed on this basis whereas 10 have been dismissed on the basis of an absence of a sufficiently serious breach. 


\section{Sufficiently serious breach}

It is notable that in commenting on Francovich the Court in Factortame $V$ found that the concepts of conferral of a right and sufficiently serious breach were 'familiar in the English law concept of tort.' At paragraph 91 the Court went further by stating that the determination of sufficiently serious breach was for national courts and not for the ECJ, because it was a matter of fact. It was acknowledged that the 'sufficiently serious breach' criterion is what makes this a 'novel' remedy from an English perspective. This is notable because although the determination of whether a breach is sufficiently serious ultimately is a matter to be determined by an analysis of the facts, the definition of the scope of the concept of sufficiently serious breach is not a matter of national law. Second, the CJEU's approach often is 'outcome' based, and therefore the Factortame judgment seems, it is submitted, to arrogate more discretion to national law than what the CJEU had envisaged.

In some cases, the Court will dismiss a claim by arguing that there is neither a right conferred nor a sufficiently serious breach of EU law. Hence, the narrow and perhaps refracted approach to conferral of a right tends to result in claims being dismissed before a detailed examination of the extent of discretion via the sufficiently serious breach condition can occur. However, in those cases in which the first condition is fulfilled the court has gone some way to expand on its understanding of sufficiently serious breach in recent case-law.

In Barco v Thanet District Council the claimants were live animal exporters who claimed that the respondents by banning the use of their port for the purposes of export, violated article 35 of the Treaty, and that the ban constituted a sufficiently serious breach of EU law giving rise to Francovich liability. Briss J. accepted that there was a sufficiently serious breach of EU law, and held that there was a direct causal link between the imposition of an export ban and the losses suffered by the claimants. ${ }^{65}$ The approach to sufficiently serious breach undertaken relied heavily on Factortame $V$ citing Lord Clyde's judgment, in particular. The question was one of 'fact and circumstance' and a question of the appropriate use of discretion. The judgment involved a detailed examination of the conduct of the respondent, and found that his conduct was disproportionate to the ends to be achieved. It would appear that Briss J. was of the view that a ban on the basis of animal welfare was a pretext its real basis being a moral and political judgment premised on animal welfare concerns. This appears to be akin to stating that the respondent acted in bad faith, although this was not explicitly stated in the judgment. As such, Briss J. found a sufficiently serious breach of EU law.

Recently, in McGouch $v U K$, a case concerning the voting rights of prisoners, the Supreme Court examined the sufficiently serious breach criterion - albeit obiter. In this case the claimants failed to show that a right was conferred on them. Thus, after rehearsing the Brasserie test, the Court held that in light of the unsettled case-law it was arguable that there was no sufficiently serious breach. Further the Court made the following remark:

Since the relevant United Kingdom authority is here Parliament in enacting and continuing in force the relevant legislation, an assessment of some of these matters (particularly whether the infringement was intentional or voluntary, excusable or inexcusable) may threaten conflict with the constitutional principle enshrined in the Bill of Rights 1688 that domestic courts in the United Kingdom ought not to 'impeach or question' proceedings in Parliament.

In order to avoid this difficult constitutional question the Court suggested approaching the question 'on an objective basis, without regard to what has actually happened or been said in Parliament.' This would, it is argued, appear to be a well-intentioned but nevertheless questionable interpretation of the test for Francovich liability by moulding it to fit national constitutional law.

\footnotetext{
${ }^{65}$ The losses claimed amounted to $£ 1.5$ million. Briss J. did not determine the issue of damages, however, in this judgment.
} 
In Negassi v Home Dept. the Court of Appeal dealt extensively with the sufficiently serious breach test. On the facts, the Secretary of State refused the claimant, an asylum seeker, the right to work on an erroneous interpretation of Article 11, Council Directive 2003/9/EC. Kay LJ referred the 'multifactorial test' for the determination of whether the breach in question was sufficiently serious. Kay LJ, following Lord Clyde in Factortame $V$, stated that in the end this test is a matter of fact and circumstance. For the stake of clarity the multifactorial test is a rehearsal of the various factors enumerated by the Court in Brasserie when examining whether a breach is sufficiently serious. These include, inter alia, the clarity and precision of the rule breached, the degree of excusability of an error of law, the existence of any relevant CJEU judgment on point, and the voluntariness or otherwise of the act/omission of the infringer of the right. These are factors aimed at determining whether a breach was manifest in circumstances in which European law leaves discretion to the national legislature as to how to implement European law, and should be distinguished from non-implementation cases in which non-implementation of European law constitutes a sufficiently serious breach per se. ${ }^{66}$ The national court's task is then to weigh these factors in a fact-sensitive manner. In the end the Court found that the factors for and against recovery were finely balanced but that the basis of the breach was a misunderstanding of new provisions of EU law which the Court found not to be 'cynical or egregious'. It is arguable that this is to add to the test a new and more exacting condition i.e. cynicism and egregiousness in cases of misapplication of EU law. It could be argued that this is closer to the English tort of misfeasance in public office as it implies a degree of dishonesty (cynical). Therefore, taking McGouch and Negrassi as indicative, a notable feature of these more recent claims is that they attempt to tie Francovich liability to the issue of fundamental rights protection i.e. outside traditional economic torts. These claims were ultimately unsuccessful for the reasons explained above.

The Negrassi test was applied to sufficiently serious breach in a different context in Recall $v$ Secretary for State for Media, Culture and Sport. The claim concerned the use of 'GSM Gateways' technology in the telecoms industry. The Ministry refused to allow its use, and the claimants alleged damages amounting to $£ 415$ million. Rose J. (HC) decided, in the absence of a CJEU judgment on this point, that the public security justification relied on by the state was unjustified and outside its meaning in the relevant directive. She held on the basis of the test in Poole, cited above, that a right had been conferred on the claimants. However, Rose J. held that the breach of EU law had not been sufficiently serious. In so doing, Rose J. applied the multifactorial test in Negrassi, finding in particular that the Ministry weighed the arguments for public security and did not approach the matter with a closed mind. ${ }^{67}$ The error of law was held to be excusable, and not an 'egregious error'. Again, the sufficiently serious test was applied in a highly fact-sensitive manner and seemed to be closely based on the bona fides, or otherwise, of the relevant Governmental department.

\section{Conclusion}

In conclusion, it appears that in the United Kingdom a narrow reading of 'conferral of a right' has led to muted reception to Francovich liability. In those judgments which have treated 'sufficiently serious breach' the claimants have been mostly unsuccessful. In recent years the courts appear more willing to examine the sufficiently serious breach question. However, in most of the cases they ultimately dismiss the claim. An exception to this approach is Barco, in which the conditions for a sufficiently serious breach were held to be fulfilled. However, the factual circumstances were such that the breach could be characterised as mala fides on the part of the respondents. On the facts, however, the Francovich remedy filled a remedial gap.

\footnotetext{
${ }^{66}$ This distinction is, however, questioned in light of the Brinkmann (?) judgment.

${ }^{67}$ Para. 202.
} 


\section{Conclusions}

Rónán Condon and Barend van Leeuwen (PhD Researchers, European University Institute)

\section{Summary of findings}

The research undertaken indicates that there is no single clear pattern as to the relevant legal issues that have arisen with regard to how national law interacts with Francovich liability. This is, perhaps, to be expected since Francovich liability requires only minimum harmonisation of liability, and Member State courts may, if they so choose, go beyond the minimum conditions of liability to impose more exacting standards on Member States in light of their own legal traditions of State liability. A second reason why we might not expect that the relevant legal issues are similar in each jurisdiction devolves from the very difference in legal tradition and institutional structure that raises different legally relevant questions in each jurisdiction. We propose to briefly point to the different legal issues raised before indicating the subject-matter at issue, and finally, examining the treatment of a specific condition of liability, namely, 'sufficiently serious breach'. The latter aims to examine how national courts have treated the most distinctive condition of liability with a view to explore, at least in a preliminary manner, the patterns which have developed at national level, and to speculate as to the reasons why they have developed.

\section{Main legal issues}

In the common law jurisdictions, Ireland and the United Kingdom, the courts have mainly grappled with the conditions of liability. In the United Kingdom, the courts focus on the first and second condition of liability, conferral of a right and sufficiently serious breach. In Ireland, by contrast, the emphasis is placed on causation mainly as a means to deny recovery. The Irish High Court, in particular, has on occasion found ways to avoid a discussion of Francovich liability by referring to national law remedies instead. In Poland, the courts have invoked causation to deny recovery, although given the paucity of judgments it is difficult to extrapolate links to the Irish approach.

In France, the courts have also concentrated on the question of causation. This is perhaps unsurprising because in French national law causation is the main control mechanism used by the courts - the question of whether a legal bond exists being an easier hurdle to surmount. In Italy, the question of Francovich liability has developed according to the more general debate about the primacy of European law. At first, the Court's attitude towards recovery can be characterised as recalcitrant. Over time, however, the Court has come to re-fashion its substantive law to make recovery more than a hypothetical possibility by, in particular, re-framing the basis of recovery to extend time-limits. This approach is not dissimilar to that taken in Finland, in which the courts initially were reluctant to award recovery relying on a number of national procedural and substantive bars that penalised claimants who brought Francovich claims based on national rules which limit recovery against public authorities. However, in recent years this approach has been relaxed, and a number of cases are pending before the courts. Nevertheless, as the Finland report indicates, there remain a number of procedural bars that inhibit recovery.

The Dutch courts now appear to have gone beyond the minimum conditions of liability by dispensing with the requirement of sufficiently serious breach, and allow recovery more liberally, at least in theory, than most other jurisdictions. In Spain, by contrast, and notwithstanding the high number of successful claims deriving from the Spanish State's non-implementation of the Sixth Directive on VAT, the treatment of domestic claims against the state appears to be more favourable than those under the head of Francovich liability. This is questionable from an equivalence perspective, a theme that is developed below with regard to the condition of sufficiently serious breach.

In Germany, the courts have awarded damages in a considerable number of cases on foot of the Fuss judgment of the CJEU. However, it is submitted that the courts have followed a minimalist approach 
to Francovich liability. The courts seem unwilling to find a sufficiently serious breach in the absence of a prior judgment of the CJEU holding the state in breach of EU law.

Finally, in Greece the courts seem to have particular difficulty with implementing the Köbler judgment. In those cases not involving the liability of the judicial branch of government, the Greek courts appear willing to award recovery.

\section{The relationship between State liability under national law and State liability under EU law}

One of the important themes of the national reports is the relationship between State liability under national law and State liability under EU law. Does Francovich State liability remain an autonomous remedy at the national level or is it incorporated in or adopted by national State liability law? The alternative is that given the flexibility inherent in the sufficiently serious breach condition, which is ultimately a question of the proper use of discretionary power, states might fall back on their national categories of recovery, going below what is minimally required by the remedy.

It is clear that in most Member States Francovich State liability remains a separate and isolated remedy. Judges have had difficulties to characterise the remedy and have used expressions such as 'sui generis' to illustrate the self-standing character of the conditions for State liability under EU law. ${ }^{68}$ The need to keep Francovich State liability a separate remedy has been particularly visible in Member States with less developed systems for State liability under national law, such as the United Kingdom and Ireland. However, in Member States in which State liability was already before the incursion of EU law relatively well-developed, such as France, it is claimed that Francovich has been silently adopted without too much reference to the precise requirements imposed by EU law. ${ }^{69}$ France is a particularly interesting example, because it has separate liability regimes for different kinds of State acts. Each of these regimes has slightly different conditions for liability. The question then becomes how Francovich State liability is integrated in each of these regimes. However, we note that although certain jurisdictions such as France or Greece traditionally have a more developed form of State liability, this does not imply that these jurisdictions integrate Francovich liability unproblematically. For example, in Greece, a jurisdiction which borrows heavily from French law, it is clear that the courts often elide Francovich liability and recovery under article 105 of the Greek Civil Code. Now, one might expect that this means that State liability is, therefore, more effective because equivalent national remedies exist. This is not, however, necessarily the case because a similar tendency to that evidenced in common law jurisdictions, which fits State liability into the national State liability regime, is evident. In Greece, the possibility of a Köbler-type claim was dismissed as a matter of principle, which is clearly contrary to the Francovich doctrine as developed by the CJEU. This is notwithstanding the fact that recovery is general is more easily obtained in situations in which recovery would be available in national law for unlawful acts of the state.

It is claimed, therefore, on the basis of the research conducted, that although the courts formally recognise the separate and autonomous nature of Francovich liability, in practice, the interpretation of the conditions of liability evidences a tendency to interpret Francovich in accordance with pre-existing national approaches to recovery against the state. By this approach, we intend to use 'sufficiently serious breach' as an example or a heuristic with which to probe the degree to which Francovich has been integrated into the national laws of the Member States surveyed. Therefore, for the purposes of our conclusions we will examine the manner in which the condition of sufficiently serious breach has been integrated in a number of the jurisdictions surveyed to give a non-exhaustive account of this process. We hope to examine these findings more exhaustively at a later point; for now, our conclusions are by way of provisional findings only.

\footnotetext{
${ }^{68}$ See the reference to the judgment of HHJ Toulmin in Factortame VI [2000] EWHC 179 in the report on the United Kingdom.

${ }^{69}$ See the report on France.
} 
Before turning to the question of sufficiently serious breach, we propose to outline the areas in which Francovich claims have been brought and the success rate of claimants.

\section{The areas of law in which Francovich claims have been brought and the success rate}

In general, it has proven difficult to identify clear patterns or similarities across the Member States in the areas of law in which Francovich claims have been brought and the areas of law in which these claims have been most successful. However, two observations can be made. First of all, a significant number of cases have been brought in the area of employment law and social security. This is also the area which appears to have the highest success rate. Secondly, there have also been a high number of cases in the field of taxation and VAT. It will be remembered that the original Francovich case was an employment law case which concerned Directive $80 / 987^{70}$ on the protection of employees in the event of the insolvency of their employer. This case appears to have triggered a series of other cases and has led to claims in Spain, France and Germany. However, there are more directives which have caused problems for the Member States. In particular, various claims were based on the Directives on working time and aspects relating to working time. ${ }^{71}$ Employees with irregular working hours, such as doctors, ambulance drivers and those in the fire services, have brought claims against the State in various Member States. Furthermore, a number of claims have been based on directives dealing with equal treatment in employment and social security. ${ }^{72}$

What could be the possible reasons for the high amount of claims in employment law? One possible explanation could simply be that the directives in the field of employment and social security have been particularly difficult for Member States to implement. It could also be that the direct interference by the EU with national social legislation - which can definitely not be regarded as purely marketfacilitative - might have resulted in opposition at the national level and in an unwillingness to correctly implement the European directives. A second explanation could that these directives are one of the best examples of conferring individual rights to persons - in most cases employees. These employees use the possibility of State liability as a tool to enforce their rights in national courts. From that perspective, a link can be made to fundamental rights protection in the EU. Many directives in this field have a strong fundamental rights dimension - in particular those on equal treatment - and through the creation of Francovich State liability the CJEU has made a contribution to the enforcement of fundamental rights protection at the national level. This is reinforced by the recent emphasis of the CJEU on Article 47 of the Charter, which protects the right to effective judicial protection. $^{73}$

Another area in which Francovich claims have been quite prominent is the field of taxation and VAT. This is not very surprising - taxation is directly linked to national sovereignty and Member States have been resisting too much direct EU influence. Furthermore, many of the taxation cases - unlike the VAT cases - have been brought directly on the basis of the Treaty articles, such as the right to free movement of establishment or capital. Without a specification of the Member States' obligations through the adoption of a directive, it has often been uncertain what exact obligations the Treaty

${ }^{70}$ Council Directive 80/987/EEC on the approximation of the laws of the Member States relating to the protection of employees in the event of the insolvency of their employer.

${ }^{71}$ For example, Directive 2003/88/EC concerning certain aspects of the organisation of working time and Directive 93/104/EC concerning certain aspects of the organisation of working time.

${ }^{72}$ For example, Directive 2000/78/EC establishing a general framework for equal treatment in employment and occupation, Directive 2000/43/EC implementing the principle of equal treatment between persons irrespective of racial or ethnic origin, and Directive 2004/113 implementing the principle of equal treatment between men and woman in the access to and supply of goods and services.

${ }^{73}$ See M. Safjan and D. Düsterhaus, 'A Union of Effective Judicial Protection: Addressing a Multi-level Challenge through the Lens of Article 47 CFREU', (2014) Yearbook of European Law (Advance Access Online). 
articles imposed on Member States. This means that the CJEU has had to play an important role in clarifying whether national legislation on taxation was in breach of the free movement provisions. As a result, national courts have been very reliant on the guidance from the CJEU and have been reluctant to find a sufficiently serious breach of EU law in the absence of a clear judgment of the CJEU.

\section{Conditions of liability}

A note of caution

It might be argued that a too narrow focus on a specific condition of liability is apt to blur the plasticity with which the courts use to the conditions of liability to achieve their desired end. Nevertheless, by focusing on how national courts 'interact' with the conditions of liability invoked to deny or to infer liability tend to fit national orthodoxy as regards what is considered the important legal questions regarding attribution of legal responsibility to the state.

To wit, in the UK and Germany the focus tends to be on the first two conditions of liability, namely, conferral of a right and the issue of sufficiently serious breach. These conditions might be thought to parallel the question of duty of care, and standard of care. Is there a legal bond between claimant and respondent, and what to what standard should the state be held accountable?

For example, in the UK our analysis suggests that the interpretation of conferral of a right has been narrow to the extent that it might be thought to elide Francovich liability with the conditions required for direct effect. ${ }^{74}$ This might be considered to be a departure from EU law - although in this respect the CJEU has itself been less than clear as regards what conferral of a right involves, and the UK courts might be forgiven for this particular elision. ${ }^{75}$ Similarly, in Germany we can deduce from the Paul reference that the issue of the creation of a iuris vinculum is an important matter for the courts. It might explain the tendency of the courts only to frame the question of sufficiently serious breach as a matter of decided cases of the CJEU. In other words, even if a right is said to have been conferred, hence a prima facie 'duty' exists, the liability question at the sufficiently serious breach stage depends on a clear precedent judging that a violation of EU law has occurred. This implies that the courts are reluctant to tie a violation of rights to a remedy, which fits the general pattern of German State liability jurisprudence that is wary of inferring protected interests outside of clearly defined classes of relationships.

In addition, it is a commonplace that in France the question of protected interest plays a secondary role as a control mechanism to that of causation. Therefore, it is not surprising that in France the analysis focuses more on the question of causation. What a direct causal link implies draws heavily on the existing interpretation of 'causality' in national law. To be sure, what a 'direct causal link' requires is the CJEU's least-developed condition of liability and, once again, it is unsurprising that national courts have turned to its existing law to develop this condition. The extent to which this interpretation departs from an adequate interpretation of effectiveness, as distinct from equivalent, remains open, and we will do no more than point towards it in our conclusions. We simply note that traditionally in French law causation is the point at which control mechanisms are employed and not at the conferral of a right or standard of care stage, and it is telling, therefore, that in contrast to the UK courts, the most relevant discussion in France pertains to this condition of liability. ${ }^{76}$

Leaving to one side the first and third conditions of liability, the introduction of the condition of a sufficiently serious breach has been the most innovative aspect of the State liability regime introduced

\footnotetext{
${ }^{74}$ See Prechal Directives in EU Law (2005) for an extended discussion of this issue of conceptual confusion.

${ }^{75}$ Contrast Dillenkofer and Peter Paul. See N Reich, who refers to the test post-Paul as resting on an 'objective schutznorm theory'.

${ }^{76}$ D Fairgrieve State Liability.
} 
by the CJEU in Francovich. As a result, it can be said that this condition is the most autonomous condition for State liability under EU law. We propose to examine this condition in more detail than the other conditions of liability for the remainder of our conclusions.

\section{Sufficiently serious breach}

The logical consequence of its novelty is that this condition has also been the most difficult one for Member States to integrate in their national State liability regimes. It will be recalled that in Brasserie $d u$ Pecheur/Factortame the Court developed this condition of liability significantly pointing towards the factors that should be taken into account when deciding whether a breach is 'sufficiently serious' and stated that the breach must be 'grave and manifest'. These factors were not intended to be exhaustive but nevertheless serve as guidelines for national courts to frame their enquiry. The English courts have referred to this 'test' as a 'multifactorial' one which is perhaps a good approximation for what was intended by the CJEU. The CJEU, in particular, stressed that the threshold of recovery varied with the extent of the discretion available to national authorities and, secondly, that the sufficiently serious criterion does not equate to negligence or mala fides. ${ }^{77}$ In other words, the condition is an autonomous European condition of liability. When examined in terms of the other remedial approaches available to a claimant (direct effect, Marleasing) Francovich appears as a remedy of last resort. ${ }^{78}$ This residual role for Francovich liability must, however, be balanced against the rights-protection dimension to the remedy - most recently stressed in AGM-Cos.met which indicated that recovery is not simply a hypothetical possibility, or, a type of recovery available only for the most egregious violations of the Treaty. ${ }^{79}$ In any event, the 'multifactorial test' means that considerable scope remains for national courts to shape Francovich liability according to the facts of the case with the guidance of the CJEU.

With respect to the sufficiently serious breach condition, we claim that the difficulties in integrating Francovich liability into national law can be divided according to whether the Member State has a broad or narrow tradition of State liability. In those jurisdictions in which a broad pre-existing regime of liability exists the problem is one of equivalence of protection. In those jurisdictions in which threshold issues have stymied State liability claims or confined it to narrowly defined classes of individuals, the problem is one of effective protection. We examine, therefore, sufficiently serious breach under the rubric of equivalence and effectiveness of EU law.

\section{Effectiveness}

In the UK the courts have gradually developed the sufficiently serious breach test in a manner which emphasises the 'intentionality' or bad faith of the state as a precondition of recovery. The courts are deferential to the executive in areas in which the exercise of administrative discretion is required, and, as such, it appears particularly 'egregious' behaviour is required on behalf of the executive before recovery will be countenanced. In addition to unlawfulness per se, i.e. illegality, a requirement of culpability is required. It should be noted that this approach is broadly in line with the general

\footnotetext{
${ }^{77}$ It seems that non-implementation is a per se breach. However, the water was muddied so to speak by Brinkmann in which non-implementation of EU alone was insufficient grounds for recovery because the national administration had taken positive steps to implement EU law notwithstanding the failure to implement EU law in time. Brinkmann can be interpreted as a judgment that turns on causation because the plaintiff could not point to negative effects of non-implementation in light of the actions of the administration. Another way to read the judgment is that the CJ takes a pragmatic view of the conditions of liability engaging in a type of equitable analysis and asks whether it is just and reasonable to impose liability as distinct from a formalistic analysis which applies the conditions of liability mechanically.

${ }^{78}$ Chalmers \& Monti.

${ }^{79}$ Compare Negrassi.
} 
approach taken in respect of administrative action, which requires a degree of unlawfulness that can be described as unreasonableness meaning irrationality. In Barco, one of the few judgments in which a claimant succeeded, the motives of the respondent were questioned and the Court inferred that the administrative actions taken which interfered with the claimant's Treaty freedoms (free movement of goods) was motivated by political expediency and not by a genuine attempt to protect animal welfare. In consequence, it could not be said that the acts rested on a rationally justifiable basis. Other English judgments support the claim that the Court requires an element of bad faith as well. ${ }^{80}$ In a multifactorial test where the question of the use of discretionary powers is at issue, it might be argued that the arguments for or against recovery are finely balanced, and as such culpability plays a decisive role as distinct from forming a test in of itself. Notwithstanding this possibility, the pronouncements of the courts seem to suggest the bad faith element is an additional or supplementary condition of recovery imposed by the courts. In any event, the degree to which the culpability requirement above approximates fault can be debated. In fact, the requirement appears to be of a higher order because negligence at common law is judged according to an objective standard of care. The UK courts appear to require subjective fault, which is more stringent than ordinary negligence and more consistent with the general approach to the liability of public authorities which places policy mechanisms over-andabove fault to limit recovery.

In Ireland, it has been averred to that the 'sufficiently serious' requirement has not been treated in any great detail. The courts prefer to dismiss claims on the basis of causation, allowing for argument's sake that the sufficiently serious breach criterion has been established. It is questionable, however, that this implies that sufficiently serious breach would in the event of a clear causal link be dealt with on its own terms or whether a type of refraction process would occur as described in our report on the UK.

\section{Equivalence}

In the civil law jurisdictions examined above, the question as to the treatment of sufficiently serious breach appear to devolve to one of what is referred to in the case-law and literature as a question of equivalent protection vis-à-vis national law. In particular, the questions arises what happens when the conditions for State liability under national law are more favourable to claimants than the Francovich conditions. For example, Spain has a State liability regime which is based on strict liability. This means that, in principle, the conditions for State liability under national law should be more easily satisfied than the conditions for Francovich State liability. It would not seem to be necessary to apply the Francovich conditions. In Germany, on the contrary, State liability under national law is only awarded if the State has been at fault - the breach of law must have been either intentional or negligent. ${ }^{81}$

What happens when national State liability law is based on strict liability and should be more favourable to claimants than Francovich liability? Two different approaches can be identified in the reports. First of all, Spanish courts have consistently used the sufficiently serious breach condition to dismiss claims for State liability. In several cases Spanish courts held that the administration enjoyed a broad margin of discretion which meant that the breach of EU law was not sufficiently serious. ${ }^{82}$ However, under national law the administration would not have enjoyed the same margin of discretion - the liability would have been strict in those cases. Therefore, it seems that Spanish courts are applying a more favourable standard to claims for State liability brought under national law than for claims brought under EU law. This is in breach of the principle of equivalence, since more favourable

\footnotetext{
${ }^{80}$ Negrassi.

${ }^{81}$ See also T. Lock, 'Is private enforcement of EU law through State liability a myth? An assessment 20 years after Francovich', (2012) 49 CML Rev 1675.

${ }^{82}$ See the report on Spain.
} 
criteria are applied to claims under national law. Interestingly, this means that the strict adherence of Spanish courts to the conditions for State liability which have been laid down by the CJEU could in itself constitute a breach of EU law.

A different approach has been adopted in the Netherlands. However, it should immediately be emphasised that this approach was only adopted last year and has not yet been confirmed by the Dutch Supreme Court. For many years Dutch courts faithfully followed the conditions for State liability laid down in Francovich and Brasserie du Pecheur. ${ }^{83}$ However, last year the Court of Appeal of The Hague held that, under Dutch law, the adoption of legislation which was in breach of a superior law including EU law - was sufficient for the State to be held liable to pay damages. As such, there was no requirement of a sufficiently serious breach under national law. ${ }^{84}$ The Court held that the conditions for Francovich State liability were only minimum conditions and that national law could go beyond the requirements imposed by EU law and could be more favourable to claimants. As a result, the Francovich conditions would now appear to have become obsolete in the Netherlands. It has become much easier for claimants to claim State liability for a breach of EU law. In principle, unlike the Spanish approach, this new Dutch approach appears consistent with the equivalence principle. However, it is not clear how broad its scope of application is.

A more general problem is that before the ECJ's judgment in Köbler ${ }^{85}$ many Member States did not provide for liability for acts of the judiciary. State liability has been extended to include such acts within the scope of State liability in order to comply with EU law. The question is then whether the equivalence principle still applies to this new type of State liability which did not exist under national law before Köbler. The simplest answer would be to say no, as there is no similar liability for acts of the judiciary under national law. At the same time, it is not clear whether for the purpose of the equivalence test national State liability law should be considered as a whole or whether a distinction between different types or heads of liability can be made. If this is permissible under EU law, the equivalence test would be satisfied because there would not be a similar claim under national law which was treated more favourably than a claim under EU law.

Finally, it is clear that the German courts have applied the Francovich conditions for State liability. The result is that the conditions for State liability under EU law are more easily fulfilled than the conditions for State liability under national law, for which there is a fault requirement. As such, it could be said that EU law claims are treated more favourably than national law claims. One could expect the difference to encourage a general reform of German State liability law, but this has not taken place. As a result, Germany continues to have two separate regimes for State liability.

\section{Conclusion}

Our conclusions strike a cautious note. It is clear that the courts in each Member State have examined Francovich liability claims on their merits. The qualitative analysis indicates that State liability claims are reaching the courts, the merits and demerits of each claim questioned, if ultimately in most cases the claimant does not succeed in obtaining redress. Although the success rate - judged as the number of claimants which ultimately receive compensation - is low, it would be too hasty a judgment to suggest that this implies the remedy is merely hypothetical or of marginal importance. It can be argued, to the contrary, that the possibility of a liability claim incentivises compliance with EU law. One might therefore argue that judged as a deterrent Francovich is 'working'. In addition, one might

\footnotetext{
${ }^{83}$ Case C-46/93, Brasserie du Pecheurv Bundesrepublik Deutschland, [1996] ECR I-1029.

${ }^{84}$ Judgment of the Court of Appeal of The Hague of 15 October 2013 (ECLI:NL:GDHA:2013:3791).

${ }^{85}$ Case C-224/01, Gerhard Köbler v Republik Österreich, [2003] ECR I-10239.
} 

argue that given the other remedies available to claimants short of state liability, the remedy is, and should only be, invoked in a residual manner - when cooperation between Member States and the EU breaks down.

Nevertheless, a particularly pertinent finding of our research is that the substantive criteria of recovery take on a 'life of their own' once they are applied by national courts. National courts draw on their own national traditions of State liability to filter Francovich claims. This is particularly manifest when one considers how the UK courts deal with the application of the sufficiently serious breach criterion. It is evident, however, when one examines how Member States which traditionally have a more extensive form of recovery against the state interpret the conditions of liability, and, in particular, develop their law in light of which branch of government is the addressee of liability claims.

Thus, the hybrid nature of the remedy does not equate in all circumstances to equivalent protection. This hybrid nature gives scope for national courts to interpret the conditions of liability, which are broad, and might be seen as minimum conditions, in light of national legal categories. If a violation is not 'egregious', a breach is not blatant, then the court is left with discretion as to whether liability should be imposed. The problem with this approach is that it can deviate from a correct interpretation of EU law.

The State liability regime operates, in fact, if not in intention, as a framework of recovery which allows for significant diversity. This calls its autonomy into question. Whereas this might be considered preferable to a top-down liability regime, with more rigidly defined conditions of liability, it poses a problem when balancing the spirit of judicial cooperation in Article 10, which implies national legal (decentralized) enforcement, against the need for effective and equivalent rightsprotection. ${ }^{86}$ Our research indicates that the balance between judicial empowerment and uniform application of law does not always yield an optimal outcome. When applied by national courts the danger is that the conditions of liability become refracted to the detriment of rights protection. This is particularly the case in circumstances where courts are reluctant to refer cases to the CJEU on the basis of the preliminary reference procedure. From our preliminary investigations, it would appear drawing on Greene's metaphor once more that old and new wines flow together. The application of Francovich liability would appear to alter its substance. The degree to which this is acceptable in a legal order based on the principle of primacy is debatable. One thing, however, is certain. The national courts contribute to the shaping of Francovich liability and do not simply apply the law developed at the European level.

\footnotetext{
${ }^{86}$ In other words, the two bases on which Francovich liability is based per Francovich.
} 


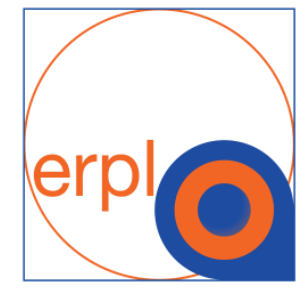

European Research Council

Established by the European Commission

This EUI Working Paper is published in the framework of an ERC-funded project hosted at the European University Institute. 